\title{
Early-Age Cracking in Concrete: Causes, Consequences, Remedial Measures, and Recommendations
}

\author{
Md. Safiuddin ${ }^{1, *}$, A. B. M. Amrul Kaish ${ }^{2}\left(\mathbb{D}\right.$, Chin-Ong Woon ${ }^{3}(\mathbb{1})$ and Sudharshan N. Raman ${ }^{3,4, *(D)}$ \\ 1 Angelo DelZotto School of Construction Management, George Brown College, 146 Kendal Avenue, \\ Toronto, ON M5T 2T9, Canada \\ 2 Department of Civil Engineering, Infrastructure University Kuala Lumpur, 43000 Kajang, Selangor, \\ Malaysia; amrul.cuet@gmail.com \\ 3 Centre for Innovative Architecture and Built Environment (SErAMBI), Faculty of Engineering and Built \\ Environment, Universiti Kebangsaan Malaysia, 43600 UKM Bangi, Selangor, Malaysia; alexwco@gmail.com \\ 4 Smart and Sustainable Township Research Centre (SUTRA), Faculty of Engineering and Built Environment, \\ Universiti Kebangsaan Malaysia, 43600 UKM Bangi, Selangor, Malaysia \\ * Correspondence: msafiuddin@georgebrown.ca (M.S.); snraman@gmail.com (S.N.R.)
}

Received: 15 July 2018; Accepted: 28 August 2018; Published: 25 September 2018

\begin{abstract}
Cracking is a common problem in concrete structures in real-life service conditions. In fact, crack-free concrete structures are very rare to find in real world. Concrete can undergo early-age cracking depending on the mix composition, exposure environment, hydration rate, and curing conditions. Understanding the causes and consequences of cracking thoroughly is essential for selecting proper measures to resolve the early-age cracking problem in concrete. This paper will help to identify the major causes and consequences of the early-age cracking in concrete. Also, this paper will be useful to adopt effective remedial measures for reducing or eliminating the early-age cracking problem in concrete. Different types of early-age crack, the factors affecting the initiation and growth of early-age cracks, the causes of early-age cracking, and the modeling of early-age cracking are discussed in this paper. A number of examples for various early-age cracking problems of concrete found in different structural elements are also shown. Above all, some recommendations are given for minimizing the early-age cracking in concrete. It is hoped that the information conveyed in this paper will be beneficial to improve the service life of concrete structures. Concrete researchers and practitioners may benefit from the contents of this paper.
\end{abstract}

Keywords: concrete; cracking mechanisms; curing; early-age cracking; mix composition; modeling; service life

\section{Introduction}

Early-age cracks are defined as cracks that generally develop within the first seven days after the placement of concrete; however, 60 days can be considered the maximum limit for early-age cracking, accounting for the initiation of cracks at the bottom of the concrete slab that may take more than one week to be visible [1].

The early-age characteristics of concrete have been a point of research interest for a long time, and researchers have focused on studying different aspects of the early-age characteristics. Bentz [2] reviewed the work on the influence of moisture, temperature, and physical/microstructural characteristics on the early-age cracking of concrete. The other examples of research study include cement hydration and microstructure development by Stark [3], and the characteristics of fresh concrete, such as flocculation, rheology, structural buildup, and formwork pressure, which were reviewed by Kim et al. [4]. Kovler and Roussel [5] focused on the properties of both fresh and hardened concretes, while Nehdi and Soliman [6] studied the mechanisms that affect the properties of concrete and its 
performance at the early age. On the other hand, Reinhardt [7] investigated the assessment methods to quantify the stiffening and hardening behavior of mortar and concrete. Mihashi and Leite [8] reviewed the mechanisms that cause complex cracking phenomena; they also focused on the methods to control the early-age cracking in concrete.

This paper provides a unique perspective on early-age concrete by focusing on the types of early-age crack, the causes of early-age cracking, the factors influencing the initiation and growth of early-age cracks, the consequences of early-age cracking, and the modeling and remedial measures for early-age cracking. Most importantly, the authors have made some key recommendations that could be very effective in reducing or eliminating the early-age cracking in concrete. This paper could act as a guideline for construction stakeholders for handling the early-age cracking problem in concrete. On the other hand, it provides a comprehensive discussion on the latest findings and identifies some research gaps in the area of the early-age cracking in concrete. However, this paper does not include any discussion on the occurrence and causes of the early-age cracking in cement paste. In practice, concrete is widely used to construct numerous structures. Therefore, it is highly practical to study the early-age cracking phenomenon of concrete.

\section{Different Types of Early-Age Crack}

Researchers have provided different perspectives on classifying the types of early-age crack in hardened concrete. One approach is grouping according to crack recovering ability. Emborg and Bernander [9] distinguished the cracking in hardened concrete to very early-age temporary or transient cracks and permanent through cracks. The transient cracks tend to close at the end of the cooling period due to compression, while the permanent through cracks do not (generally) tend to close with time. Klemczak and Knoppik-Wróbel [10] grouped the types of crack according to the type of structure, such as massive foundation slabs and medium thick structures, because concrete performs differently accordingly to its element size and structural use.

Many researchers $[2,6,8,10-13]$ grouped the cracks of concrete according to the causes of cracking, such as drying shrinkage cracks and settlement cracks, while some other researchers $[14,15]$ have grouped the concrete cracks according to the characteristics of cracking, such as random, map, transverse, longitudinal, corner, and re-entrant cracks. Figures 1-6 show some of these cracks, which initiated within 3 to 56 days after placing of concrete. However, the grouping of cracks according to the crack characteristics was not only limited to early-age hardened concrete, but also included hardened concrete at later ages, which is beyond the scope of the present study.

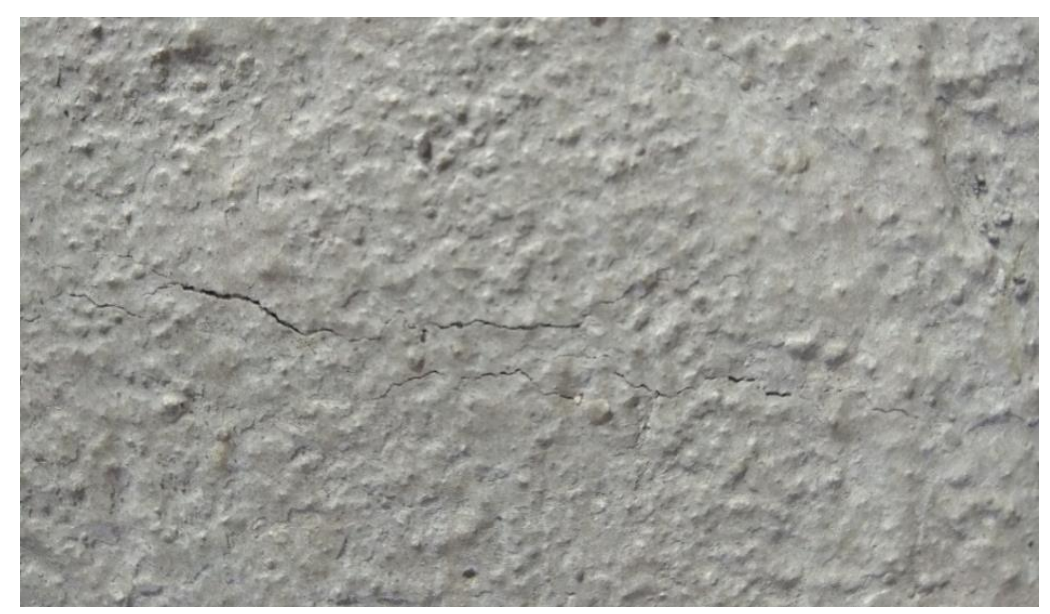

Figure 1. Early-age transverse cracks that occurred in a newly cast reinforced concrete column; these cracks occurred within three days after placing of concrete; the column was cured by wet burlap. 


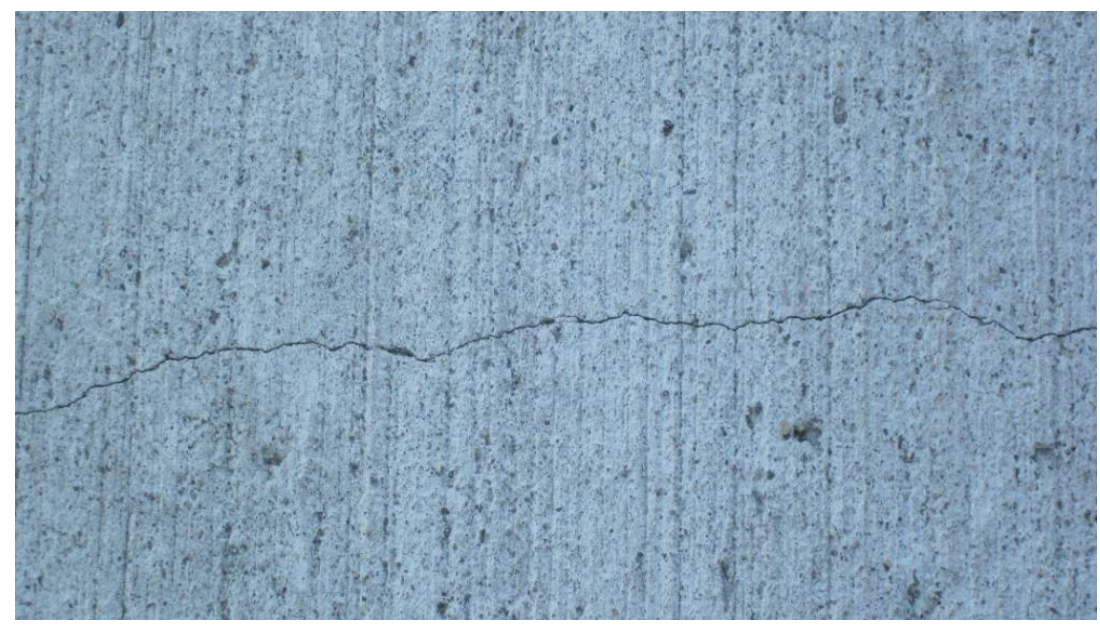

Figure 2. Early-age transverse crack in a concrete pavement slab which widened over time; this crack started within 56 days of concrete placement; the slab was cured using curing compound.

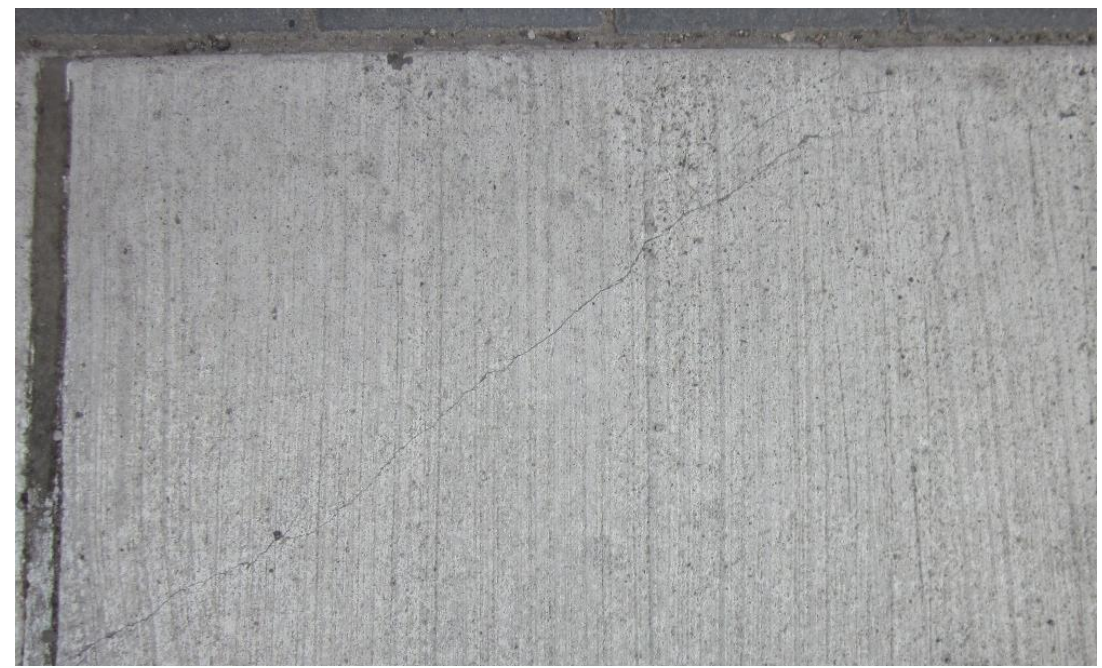

Figure 3. Early-age corner crack in a concrete side-walk slab; this crack appeared within 35 days after concrete placement; the concrete slab was cured by curing compound.

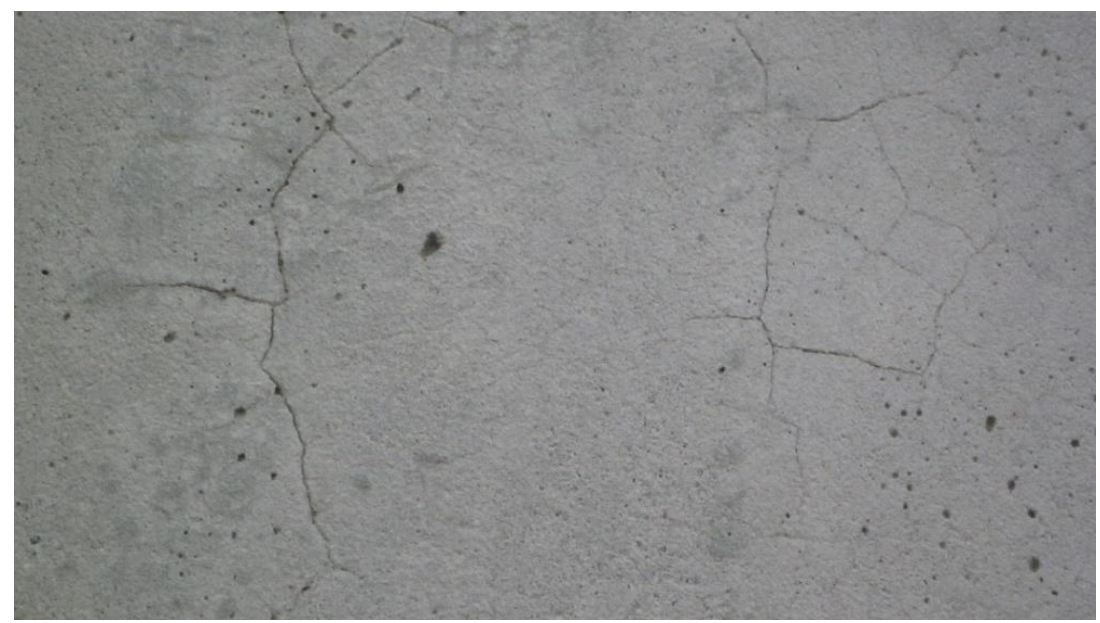

Figure 4. Early-age random cracks that occurred in a concrete floor slab; most of these cracks appeared within 42 days after placing of concrete; the slab was cured using thermal curing blanket. 


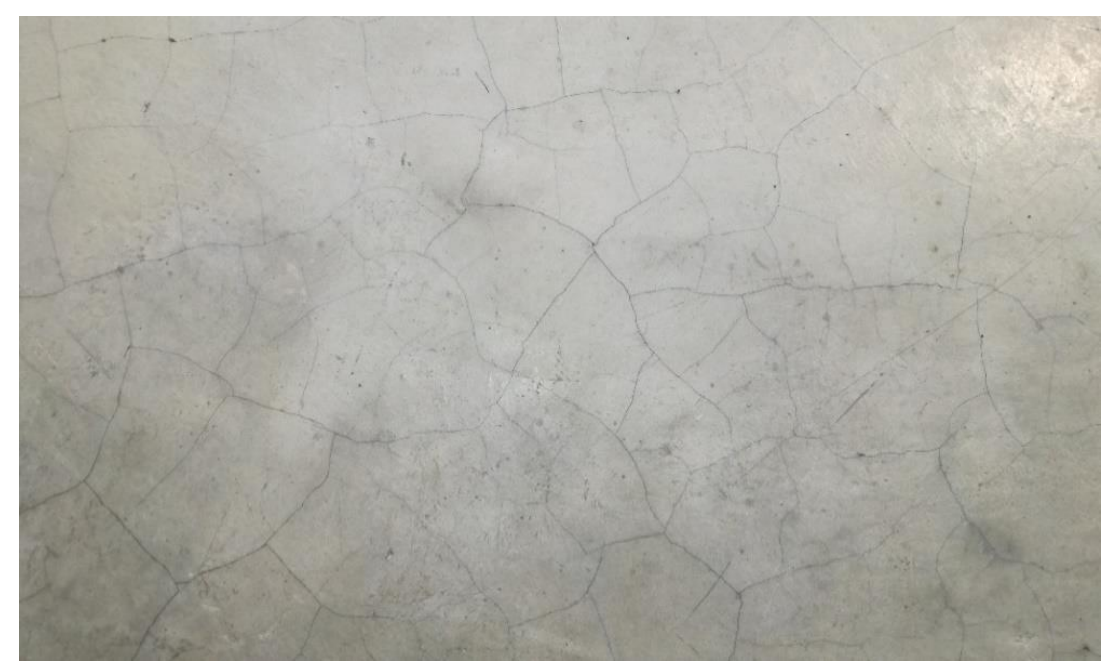

Figure 5. Early-age map cracks that occurred in a newly cast concrete floor slab; these cracks appeared within 14 days of concrete placement; the floor slab was cured by spraying of water.

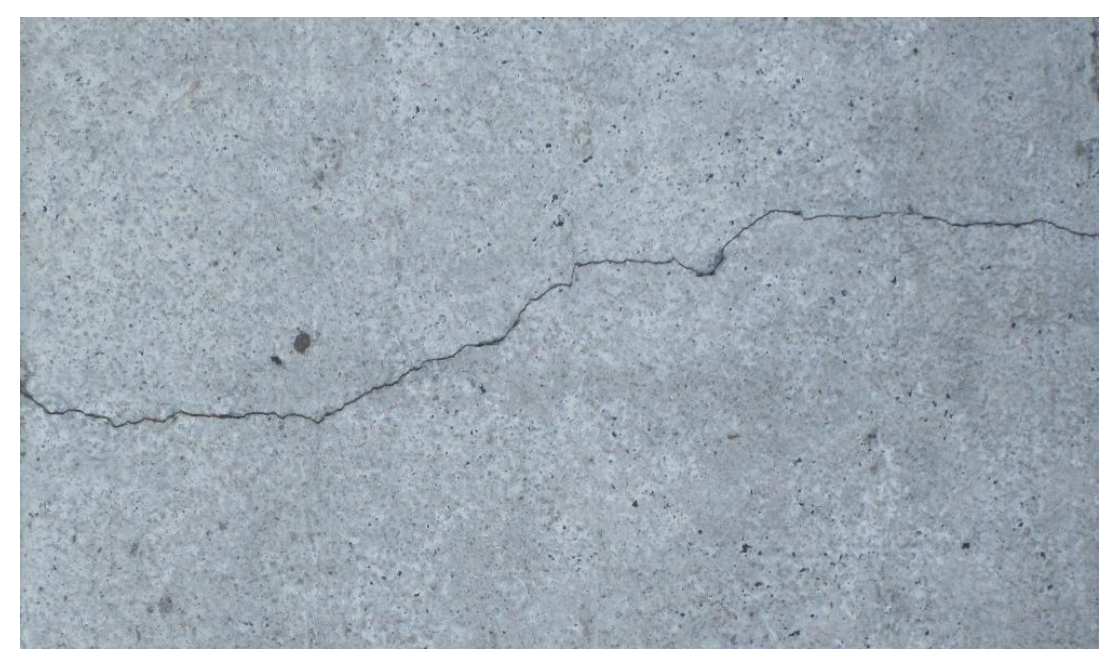

Figure 6. Restrained shrinkage cracking that occurred in a roadside concrete curb; this crack initiated within 56 days of concrete placement; the curb was cured with curing compound.

\section{Causes of Early-Age Cracking}

Early-age cracking occurs in concrete structures because of temperature differences and stress development during hardening of concrete. At the early-age of concrete elements or structures, when the tensile strain created from restrained thermal contraction or temperature differential surpasses the tensile strain capacity of concrete, cracking is the outcome (refer to Figure 6); the tensile strain may also be aroused from early contraction caused by autogenous shrinkage [16]. High-strength concrete is more prone to early-age cracking due to autogenous shrinkage [17]. Drying shrinkage hardly plays a role to cause the early-age cracking in concrete. Klemczak and Knoppik-Wróbel [10] divided drying shrinkage into two types: external drying shrinkage and internal drying shrinkage, and this was supported by Mihashi and Leite [8]. Holt and Leivo [12] divided shrinkage into three types, i.e., drying, thermal, and autogenous shrinkages.

Concrete for repair purpose requires high early strength; therefore, accelerators are commonly used in the mixture to increase hydration rate. However, the increased hydration rate also causes high heat of hydration which can potentially increase autogenous deformation and subsequent cracking in concrete [18]. Hence, the proper choice of accelerator is very important regarding the use of high-early-strength concrete in repair or overlay work. Meagher et al. [19] studied the 
effect of nitrate- and chloride-based accelerators on the cracking risk in concrete at the early-age. They reported similar cracking tendencies for both accelerator types at different concentrations. However, the concrete with the chloride-based accelerator experienced higher shrinkage compared to that with the nitrate-based accelerator.

Thermal strains driven by high temperature gradients occur between the interior and surface of structural elements since concrete has poor thermal conductivity $[8,10]$. The partial and fully restrained movement from the cooling or other temperature change induces tensile stress in concrete $[20,21]$; because early-age concrete is generally not strong enough to resist this stress, it cracks. Holt and Leivo [12] named this phenomenon as the thermal dilation effect.

Some researchers [6] have different viewpoints on drying shrinkage cracking and defined drying shrinkage as a reduction in concrete volume due to moisture loss at constant temperature and relative humidity. The loss of water through evaporation results in plastic shrinkage and subsequent internal stresses [13,22], leading to early-age map cracks on the concrete surface, as shown in Figure 5. Branch et al. [23] deduced that the presence of microsilica and the rapid drying of the concrete surface are the main reasons for plastic shrinkage in concrete elements.

Holt [24] pointed out that the chemical shrinkage and autogenous shrinkage of concrete may contribute to its ultimate cracking risk. Chemical shrinkage is induced when the volume of hydration products becomes smaller than the original volume of reacting constituents: cement and water. It is defined as the internal volume reduction in the hydrated cement paste of concrete. In contrast, autogenous shrinkage is considered as the external volume reduction of hydrated cement paste. It happens when the hydration process consumes water and causes internal drying, resulting in a decrease in the material volume $[8,10]$. At the early stage, when the concrete is still soft, autogenous shrinkage is only attributed to the chemical changes driven by cement hydration, but at a later stage (after approximately $5 \mathrm{~h}$ ), it is mostly due to self-desiccation, which is intensified by certain mix ingredients (silica fume and superplasticizer) and low water-cement ratio [24]. Therefore, there is a higher risk of autogenous shrinkage in high-strength and high-performance concretes.

Higher coarse aggregate content, the use of very fine and high-angularity sand, poor aggregate gradation, incompatible mineral and chemical admixtures, inadequate curing, delayed finishing, high rate of evaporation from concrete surface, and sudden temperature drop are the major causes of plastic shrinkage cracking. Plastic settlement is one of the common causes of early-age cracks in hardened concrete. The vertical settlement of solid particles and the associated vertical restraint result in differential settlements. Moreover, during the casting of concrete, bleed water moves to the surface, while solid particles settle downwards because of gravity. If the concrete is locally restrained from settling, the settlement of solid particles induces stress. When this stress exceeds the strength of fresh concrete, cracking will happen at the source of restraint [25].

Increased coarse aggregate fraction, the presence of very fine sand, poor aggregate gradation, incompatible chemical admixtures, deficient curing, excessively hot conditions, inappropriate control joints, too large joint spacing, and abrupt temperature changes are the main reasons of random cracking in concrete elements [1].

Early loading, the use of dry concrete mixture, poor aggregate gradation, the incorporation of very fine and highly angular sand, inappropriate materials combination, ineffective curing, improper design dimensions, defective joint design, differential support conditions, an excessively hot ambient environment, and rapid temperature decrease are the major reasons of longitudinal cracking in concrete elements. External loading factors such as vibration, traffic, and wind on hardening concrete should not be ignored. The external loading provides extra stress on concrete. However, the tensile strength of early-age concrete is relatively low although it increases with age [26]. In other words, the tensile strength of concrete is very low at the initial stage, especially during the first $3 \mathrm{~h}$, but becomes several times larger in the next few hours [27]. When the tensile stress due to external loading exceeds the ultimate tensile strength of concrete, cracking occurs in concrete. 
Higher content of coarse aggregate, unsuitable aggregate gradation, the use of very fine and highly angular sand, the incorporation of incompatible concrete constituents, inadequate curing, inappropriate element dimensions, deficient control joints, misplacement of dowels and/or tie bars, poor stability, extremely hot surrounding environment, and rapid temperature drop are the key causes of transverse cracking in concrete elements [1].

Equipment or traffic loading at the early-age, inadequate curing because of late or poor coverage, excessive curling and warping stresses caused by very long dimensions, poor stability causing excessive deflection under load, and very close dowel and/or tie bars preventing joint corner relaxation are the major reasons for corner cracking in concrete elements [1].

Skewed joints, late sawing, sawing along wind direction, and high wind are some of the reasons for pop-off cracks in concrete elements such as pavement slabs [1]. Mismatched joints in adjacent lanes, joints matching in location but of different types, and cracking from transverse joints in previously paved adjacent lanes can cause sympathy cracks in concrete pavement [1].

High workability, slow setting time, low viscosity, shallow placement of distribution reinforcement as well as dowel or tie bars, and large aggregate size are the major reasons for settlement cracks in concrete pavement [1].

The increased stress due to odd shape and cracking from interior corners can cause re-entrant cracks in concrete elements [1]. They typically originate from beam pockets, window corners, or other openings.

Issa [14] attempted to identify the causes of the early-age cracking in concrete bridge deck through literature review and questionnaire survey throughout the United States. It was deduced that the high evaporation rate and subsequent high magnitude of shrinkage are the most common causes of cracking in concrete bridge deck. The other causes of early-age cracking identified were the use of high-slump concrete, excessive heat of hydration, inefficient curing procedures, improper sequence of concrete pouring, inadequate concrete cover, insufficient compaction, inadequate detailing of joints between new and old decks, etc. [14]. Krauss and Rogalla [28] also identified the deck restraint, improper curing, high early-age modulus of elasticity, creep, shrinkage, and thermal strains as the causes of cracking in concrete bridge decks.

Concrete creep is one of the major causes of the early-age cracking in concrete elements. It is defined as the result of numerous interatomic bond breaks happening at different time periods at different overstressed sites of concrete [29]. Bažant et al. [30] divided the creep into three types: basic creep, drying creep, and transitional thermal creep. Basic creep is strongly dependent on the age at loading and water content [29]. Bažant et al. [30] divided the age at loading into short-term chemical aging and long-term nonchemical aging. The effect of hydration process on the capillary pore structure in the cement paste reduces the creep compliance of concrete [29]. This is referred to as short-term chemical aging. In long-term nonchemical aging, the cement hydration in concrete is practically stopped and the basic creep decreases while the age at loading increases [29].

Drying creep, also referred to as Pickett effect [31,32], occurs when concrete elements undergo deformation during drying as well is after drying. There are two major mechanisms for this form of creep-firstly, a macroscopic mechanism due to microcracking or strain-softening damage and secondly, a nanoscale mechanism due to stress-induced shrinkage [32]. According to the macroscopic mechanism, the nonuniform moisture distribution between the external and internal layers of concrete causes shrinkage to occur in these layers at different time periods due to the loss of water from capillary pores. Consequently, a tensile stress is induced that leads to local microcracking or tensile strain-softening damage in the surface layer, resulting in nonlinear inelastic deformation (unrecoverable creep) of concrete. The second mechanism is stress-induced shrinkage due to moisture loss and temperature rise [32]. Upon drying, a thermodynamic imbalance among the chemical potentials of various phases of pore water develops due to reduced pore vapor pressure and temperature rise [30], resulting in tensile stresses, which are balanced by compressive stresses (micro-prestress) in the surrounding concrete and consequently concrete shrinks. This phenomenon particularly occurs in the nanostructure of concrete 
comprising calcium silicate hydrates, very small capillary pores, and gel pores. The breakages of bonds in the calcium silicate hydrates may happen by an increase in the magnitude of micro-prestress.

Transitional thermal creep is defined as the transient increase of creep due to changing temperature [30]. The first mechanism is an apparent macroscopic mechanism, which is, like drying creep, owing to thermally induced microcracking. Another mechanism is the nanoscale mechanism, in which the changing temperature alters the level of micro-prestress by changing the chemical potential of nanopore water [30].

\section{Factors Affecting Early-Age Cracking}

The temperature change, thermal expansion coefficient, tensile strength, and the restraint to movement within the concrete are some of the factors that affect the early-age cracking in concrete [16]. The temperature change depends on the heat evolution in concrete, which is influenced by the amount and type of cement, the thickness of concrete element, and the ambient conditions or the type of formwork where the concrete is placed [10].

Emborg and Bernander [9] discovered that the temperature criteria only influenced hardened concrete in specific situations and the other parameters that should be considered include the type of cracking, transient mechanical properties, and axial and rotational restraints. De Schutter and Taerwe [33] studied the thermal heat and thermal diffusivity of hardening concrete and found that thermal diffusivity decreases linearly with the increase in the degree of hydration.

The factors that affect the early-age cracking in concrete are categorized into five groups, namely design process, materials and mix proportions, construction procedures, environmental conditions, and external loading conditions, as presented in Figure 7. Each group includes 2-7 different factors.

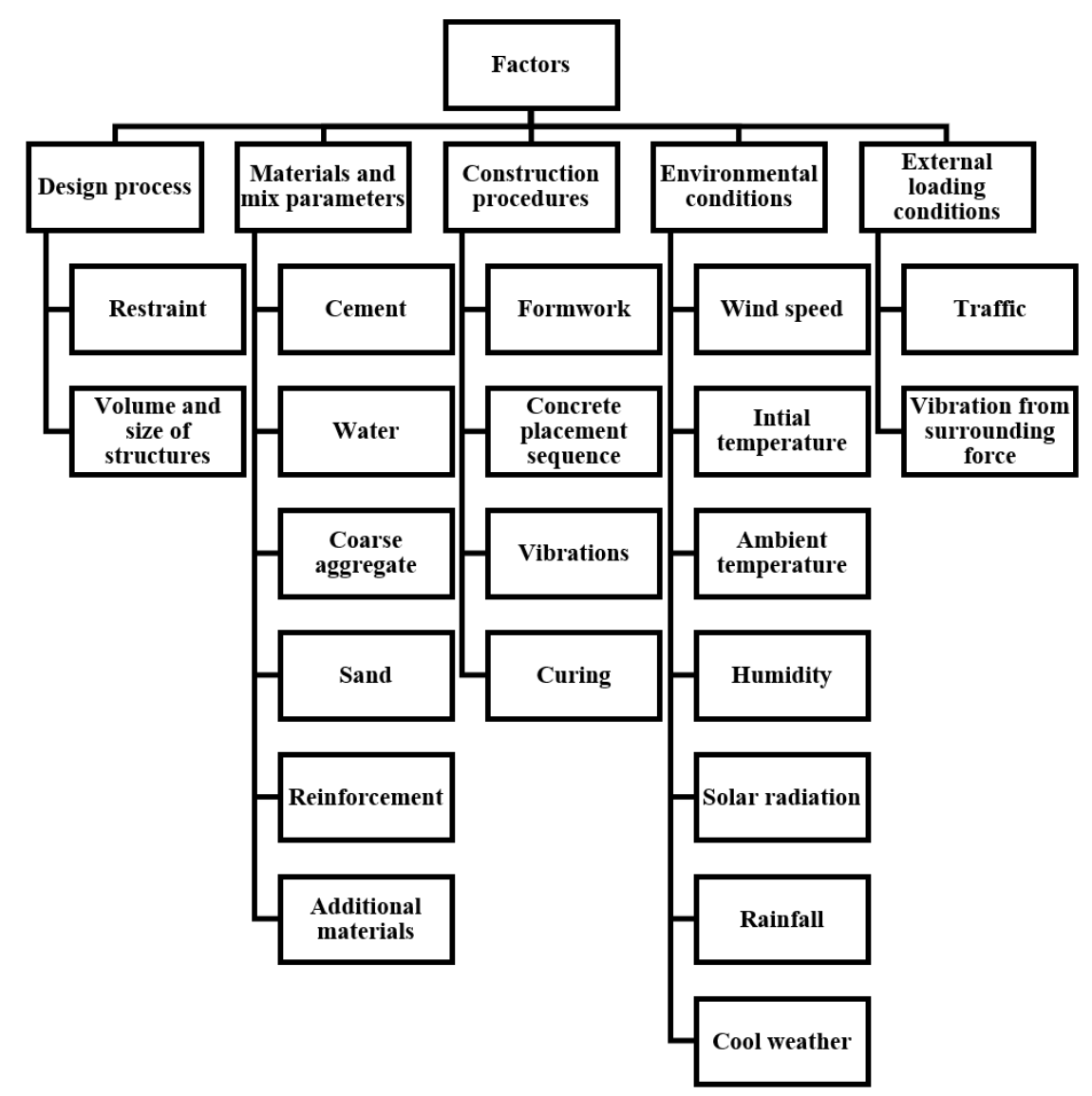

Figure 7. Various factors which influence cracking of hardened concrete. 


\subsection{Design Process}

Restraints in concrete should be considered during the design process. The restraints due to thermal and autogenous deformation induce stresses in concrete. Cracking is induced when the tensile stress / strength ratio exceeds 60\% [34]. The restrained movement depends on the design of the structure and the source of restrained movement, such as concrete cover [35], reinforcement [36,37], nonuniform concrete depth [37], and the others. The structural design detail which should be considered for the restrained movement includes the dimensions and geometry of the structure [9], location [9,34], and general structural configuration [9].

The volume/size of concrete elements is one of the main factors for thermal dilation cracking. The massivity of the structure is defined as the ratio between the volume and the exposure surface [38], while the structure is considered as massive when the structural dimensions of heat diffusion exceed the hydration heat diffusion length [39]. In massive concrete structures, the variation in the degree of hydration happens at different locations due to the low temperature coefficient of concrete $[8,10]$. Due to the differential temperature of concrete, cracking occurs in concrete because of thermal dilation. Besides, it was found that the influence of the concrete cover on the tendency of cracking is more significant than the size of reinforcement and slump. Decreasing the depth of concrete cover could increase the tendency of cracking $[40,41]$.

\subsection{Materials and Mix Parameters}

The mixing of cement and water liberates hydration heat that causes thermal stress. Thermal stress, as a result of temperature variations, may exceed the early-age strength of concrete and lead to cracking. It is therefore necessary to study the relationship between strength development, modulus of elasticity, and the coefficients of thermal expansion and contraction to predict cracking [36]. Some researchers deduced that the cement type and content can play an important role in improving the performance of concrete, because the generation of hydration heat substantially depends on the type of cement and cement content [9,12,42-44]. Different types of cement exhibit unique fineness characteristics and efficiency in terms of dispersion [12]. The lowest cement content produces the lowest drying shrinkage [36]. The particle size of cement also influences its reactivity with water. The hydration process is faster with finer cement particles, resulting in the earlier setting of concrete [25,45]. Ramézani et al. [46] reported that CEM I and CEM III slag cements (CEM: calcium-enriched mixture) are more susceptible to autogenous shrinkage cracking in mortar, which was also confirmed by the denser network of microcracking observed through scanning electron microscope (SEM) analysis. However, Lura et al. [44] pointed out that higher hydration heat does not necessarily lead to deformation and cracking, but increases the risk of cracking in concrete. Meanwhile, Kockal and Turker [47] found that using different cement types in higher strength classes with almost equal water-to-cement ratio causes no significant difference in the cracking tendency. The water content of concrete also plays an important role in concrete cracking. The compressive strength increases and the drying shrinkage strain decreases for a concrete with lower water-to-cement ratio [48,49]. However, a common problem in concrete with low water-to-cement ratio is autogenous shrinkage, which happens due to self-desiccation when the water-to-cement ratio is lower than 0.42 [50]. Conversely, when the water-to-cement ratio is increased, the concrete becomes more prone to bleeding [24]. There are larger amounts of fine particles in low-bleed concrete mixtures compared to high-bleed concrete. High-bleed concrete may produce greater differential settlement because it causes lower paste mobility and capillary pressure build-up. The potential of plastic settlement cracking increases because of the capillary pressure build-up, which increases the amount of vertical settlement [37].

Additional materials, such as mineral admixtures, water reducing admixture, shrinkage compensating cement, shrinkage reducing admixture, and self-compacting admixture have been used to improve concrete performance. The early-age cracking of concrete can be decreased by increasing the maximum allowable internal temperature difference before cracking and minimizing the thermal dilation effect of concrete, especially in mass concrete structure. Lawrence et al. [51] 
found that the concrete produced with blending 50\% Portland cement, 30\% slag, and 20\% fly ash performed better than the concrete containing 100\% Portland cement, or the concrete with 35\% Portland cement substitution with fly ash, or the concrete with $50 \%$ Portland cement substitution with ground granulated blast-furnace slag. Also, shrinkage reducing admixtures and self-compacting admixtures could reduce the drying shrinkage of concrete with the provision of adequate moist or wet curing [52] and decrease the surface tension of water [12]. They also produce lower heat of hydration, which reduces the thermal shrinkage of concrete [36]. However, it is not only the amount of hydration heat that may cause early-age cracking due to thermal gradient, particularly in massive structures. The diffusion of heat of hydration could also play a vital role. High-performance concrete has higher risk than the other concretes, because of the smaller hydration heat diffusion length [39]. A smaller hydration heat diffusion length increases the possibility of early-age cracking.

Materials selection and mix proportions or parameters, including water-to-cement ratio and the use of silica fume influence the shrinkage behavior of concrete by affecting the fineness of the pore structure in concrete. In the case of finer pores, a large compressive stress acts on the pore walls, consequently causing a greater autogenous shrinkage at both early and later ages [12]. Also, the size of aggregate influences the mechanical properties of hardened concrete; such as Young's modulus of elasticity and fracture energy that are related to the cracking behavior. A larger coarse aggregate size decreases the tensile strength and Young's modulus of hardened concrete, because larger aggregates increase the size of the transition zone, which is the weak interface between aggregate and cement paste [53]. Moreover, an increase in the coarse aggregate size decreases the cohesiveness, thus increasing the slump of concrete [53]. A high slump of concrete not only increases the possibility of cracking but may decrease the bond strength between concrete and reinforcement [14] due to more free water. The aggregates tend to reduce the autogenous shrinkage and creep due to diluting effects [54]. However, their contribution in reducing autogenous shrinkage is limited [53].

Reinforcement is able to reduce free deformation, but the effect is limited since the thermal coefficients of reinforcement and concrete are similar $[12,53,55]$. On the other hand, steel reinforcement is believed to cause undesirable surface cracks due to its restraining effects as mentioned in Section 4.1. However, the steel reinforcement has the ability to increase the tensile strain capacity of concrete and the minor cracks led by reinforcement can be delayed until the moment at which major cracks are formed [55]. The bar size also influences the cracking in concrete, where a larger bar size increases the tendency of cracking [40,41].

Cortas et al. [56] studied the shrinkage-induced early-age cracking risk of concrete due to the degree of water saturation of aggregates. They studied three different degrees of saturation $(0 \%, 50 \%$, and $100 \%$ ). They reported that the concrete with fully saturated aggregates is susceptible for the highest potential of cracking risk. This is because of the rapid evolution of modulus of elasticity from initial setting time. The concrete with partially saturated aggregates showed the highest early-age plastic and autogenous shrinkages. They also reported that the amount of added water during concrete mixing greatly affects the early-age cracking behavior of concrete. The exposure conditions, pore moisture suction, and the depth of crack are the major causes of crack propagation in concrete at the early-age [57]. Proper compaction and effective curing can minimize the severity of cracking in concrete at the early-age.

The increased amount of cementitious materials increases the risk of the early-age cracking in concrete. Therefore, high-performance concrete suffers high levels of autogenous shrinkage, tensile creep, and cracking during the early age due to the high volume of cementitious materials [11].

\subsection{Construction Procedures}

Formwork is one of the important components which influence the cracking behavior of early-age concrete. The choice of the formwork can alter the risk of early-age cracking by changing the heat exchange length and structure's surface to volume ratio [39]. The risk of the early-age cracking of concrete elements can increase due to increasing heat exchange length when the structural surface 
to volume ratio decreases. Also, the formwork material properties (especially conductivity) and the length of removal time play important roles in the cracking of concrete. Although the increased conductivity of formwork materials reduces the cracking risk at the casting stage, it increases the cracking risk later after demolding [42]. Therefore, the formwork material should be chosen carefully with special attention given to its conductivity. The removal time of formwork also needs to be optimized to control the early-age cracking in concrete.

The sequence of concrete placement should be planned properly to avoid the thermal dilation effect in concrete elements. The difference in temperature due to concrete placing sequence, formwork, insulation, cooling, neighboring structures, and other factors has a paramount effect on the temperature drop during the cooling phase. Hence, there exists the potential for contraction of the maturing concrete [9].

The consistency of hardening concrete may influence the risk of damage due to internal or external vibration. Several studies have highlighted that re-vibration could improve the compressive strength [58,59], but it has also been reported that vibration during the critical concrete age may cause external stress exceeding the strength of concrete [60]. Therefore, Akins and Dixon [61] recommended the appropriate vibration speed according to the maturity condition for traditional concrete. The other type of concrete, such as high-strength concrete, should be studied accordingly to determine the effect of vibration. In addition, the effect of blasting work close to the construction site should not be ignored. Ansell and Silfwerbrand [62] concluded that the vibration from blasting should be avoided for fresh concrete, but the vibration limit can be increased with the increase in hardening age. The researchers $[35,36]$ also pointed out that the different construction factors, such as casting sequence, supporting structure, construction equipment, the weight of the concrete deck section poured, and the weight of the construction team, formwork, and mobile construction equipment have an effect on the concrete structure. However, the vibration from the surroundings during construction, such as pile driving [63] and working coal mill [64], does not affect the compressive strength of concrete, but Ansell and Silfwerbrand [62] stated that concrete age, distance, and the type of ground are the major factors, depending on which pile driving could be a problematic issue.

Curing is another critical factor that greatly influences the occurrence of the early-age cracking in concrete. Liu et al. [42] reported that curing temperature and the temperature of fresh concrete are the two major causes of the early-age cracking in concrete. Shen et al. [65] studied the effect of curing temperature on the early-age cracking behavior of high-performance concrete. They reported that the autogenous shrinkage and subsequent cracking in high-performance concrete increase with increasing curing temperature. A curing temperature of $20^{\circ} \mathrm{C}$ was reported as the optimum curing temperature for high-performance concrete to mitigate early-age cracking. Later, they also studied the influence of water-to-cement ratio on the early-age cracking resistance of high-performance concrete [66]. They concluded that the early-age cracking potential of high-performance concrete increases with a decrease in water-to-cement ratio that causes a greater temperature rise.

Due to several reasons, such as the evaporation of water, porosity of aggregate, porosity of forms or existing structure, amount of fines in aggregate, and the distribution of water, the loss of water from concrete is expected during hydration [14]. Thus, the development of capillary pressure in concrete induces autogenous shrinkage $[67,68]$. The amount of water should be optimized to maintain the desired workability. Therefore, curing plays an important role to minimize the evaporation of water. Another method is installing insulation on the concrete surface to minimize the evaporation of water due to environmental factors. Besides, curing temperature is one of the important factors which influence the concrete properties at the early-age, because it alters the kinetics of hydration and the self-desiccation process [69]. Sule and van Breugel [55] found out that the development of the compressive strength of concrete under isothermal condition is slower than that under semi-adiabatic, but the isothermal condition produces a higher compressive strength after 28 days. 


\subsection{Environmental Conditions}

Evaporation of water is always a challenging issue during concrete construction. Therefore, many researchers $[12,23,70]$ studied this issue and identified initial temperature, ambient temperature, humidity, wind, and solar radiation as the major factors for the evaporation of water. Holt and Leivo [12] found out that humidity, air temperature, and wind velocity have a direct relationship with the evaporation rate. Also, Oh et al. [70] observed that solar radiation has a significant effect on the temperature variation of concrete after the effect of hydration heat disappears. They also noticed that dry ambient air increases the initial temperature of concrete elements, which is further increased by the hydration heat, because the initial temperature of concrete at placement becomes higher than the ambient temperature. Consequently, it may lead to inadequate concrete properties due to incomplete hydration that increase the potential of cracking. Furthermore, dry ambient air decreases the internal humidity of concrete and induces the large tensile stresses. Thus, the probability of cracking may be increased.

Briffaut et al. [71] investigated the effect of external environment on sensitivity to the formation of early-age cracks by self-restrained strains and identified that external temperature has a significant effect to reach the maximum temperature and the wind velocity mainly influences the temperature difference between the core and surface of concrete elements. Moreover, Emborg and Bernander [9] found out that the surrounding environment affects the surface temperature of adjoining structure which may contribute to cracking.

Rainfall is another challenging issue during the construction process. Rainfall increases the relative humidity of the environment. A higher relative humidity could reduce the shrinkage because it provides the water continuously for the hydration process [72]. However, it may alter the water-to-cement ratio, especially during the first-day casting. A high water-to-cement ratio can alter the mechanical properties of concrete and increase the likelihood of the early-age cracking in concrete.

Cool weather is also not favorable for concrete placement in cold regions. The constructors face certain challenges to place concrete during winter, especially for "thin" concrete structures, mainly due to the temperature and hydration progress in the entire structure. The thermo-activation of the hydration rate induces a negative effect on the structural stability at formwork removal [39].

\subsection{External Loading Conditions}

Traffic affects the strength development of hardening concrete by reducing the final bond of new concrete to existing concrete and reinforcement $[67,73,74]$. However, it may not be always applicable for all locations of concrete element $[14,62,63,75]$. It can be prominent in the region close to the joint between the new and old decks, particularly in the case of the dowels protruding from old to new concrete [14]. However, traffic loading affects high-slump concrete, especially for the slumps higher than $175 \mathrm{~mm}$ [41]. Ansell and Silfwerbrand [67] also concluded that the speed limitation and access restriction of heavy truck traffic during construction are the main factors in minimizing the risk of damaging the hardening concrete.

\subsection{Summary}

Various factors discussed under the aforementioned five different groups are more or less covered in the list shown in Table 1. Nehdi and Soliman [6] identified these factors through a comprehensive literature review. These factors influence the thermal and mechanical properties (refer to Table 1) of hardening concrete that are linked with the early-age cracking behavior of concrete. 
Table 1. Factors which influence the thermal and mechanical properties of hardening concrete.

\begin{tabular}{ll}
\hline \multicolumn{1}{c}{ Properties } & \multicolumn{1}{c}{ Factors } \\
\hline Thermal Properties: & $\begin{array}{l}\text { The type, total content, and chemical composition of cement; the ambient } \\
\text { temperature and the admixtures used. }\end{array}$ \\
\hline Heat of hydration & The mixture composition, moisture content, and ambient temperature. \\
\hline Specific heat capacity & $\begin{array}{l}\text { The density, water content, temperature, and mineralogical characteristics } \\
\text { of aggregates. }\end{array}$ \\
\hline Thermal conductivity & The aggregate type used and water content. \\
\hline Thermal diffusivity & $\begin{array}{l}\text { The type and content of cement, the type of aggregate, and water-to-cement } \\
\text { ratio; the age, temperature, and relative humidity of concrete. }\end{array}$ \\
\hline Mechanical Properties: & $\begin{array}{l}\text { Calcium silicate hydrate (CSH) gel/space ratio, water-to-cement ratio, } \\
\text { the type of cement, the presence of additives, and curing condition. }\end{array}$ \\
\hline Compressive strength & The type, density, and grading of aggregate; curing type and concrete age. \\
\hline Tensile strength & $\begin{array}{l}\text { Concrete temperature, water-to-cement ratio, cement type, aggregate } \\
\text { properties, and curing conditions. }\end{array}$ \\
\hline Modulus of elasticity &
\end{tabular}

\section{Consequences of Early-Age Cracking}

Early-age cracking is a common occurrence in concrete structures. However, early-age cracks do not cause the failure of concrete structures if the structural tolerance level is not exceeded [76]. However, these cracks affect the appearance of structures and raise public concern and attention regarding safety issues. The experts (engineers, architects, and concrete practitioners) understand that early-age cracking does not usually affect the general safety of structures. On the other hand, the public may not understand this. As a result, the image of contractors and consultant may be affected, where the public may blame the construction stakeholders for the lower construction quality. The aesthetic appearance of concrete structures is also greatly affected due to the early-age cracking in concrete surface if not repaired.

Early-age cracking, if left unchecked, may lead to long-term maintenance issues. This early-age cracking may be a temporary shortcoming, but the owners or building management personnel assign contractors to repair early-age cracks rapidly. Improper remedial work leads to further problems, such as water ponding. If these cracks are permanent and are not solved immediately, they could also allow the ingress of aggressive agents, such as chloride, sulfate, and carbonates, which may induce the corrosion of steel reinforcement and the carbonation of concrete to shorten the service life of concrete structures $[60,77,78]$.

The function of some concrete structures may be affected over time, especially in structures like water reservoirs and roofs, due to early-age cracking. The cracking may cause leakage in these structures [79]. If the concrete cracking continues to develop, it may affect the bearing capacity of the structure and speed up fatigue failure $[10,80]$. Moisture leakages are also harmful to building users and their property, especially to electronic devices. Further research in related topics is encouraged since literature in this area seems to be scarce.

Cracking is not allowed on certain special functional structures, such as nuclear power plants, chemical and radioactive waste storages, nuclear containment vessels, liquefied natural gas tanks, and waste disposal structures. It would be a disaster if the chemicals leak through these structures [81]. These leaking agents are very aggressive and harmful, where they not only pollute the environment, but are also very harmful to humans.

\section{Modeling of Early-Age Cracking}

It is complex to quantify the early-age fine cracks in construction practice. Many models are available to calculate the crack width based on the bond behavior of hardened concrete and 
reinforcing steel as well as the development of tensile stresses. The effect of reinforcement has not been considered in crack width calculations. This may be reasonable for normal-strength concrete but not for high-strength concrete. This is because reinforcement produces a "strain enhancing effect" in high-strength concrete that reduces the probability of major through-cracks in reinforced concrete elements [17].

Simulation and modeling are useful to find the uncertainties and weak spots in experimental studies and allow quantitative prediction. Thus, many researchers take the effort in developing and improving the models to provide a better understanding and predict the cracking in concrete at the early-age. Francesco et al. [82] provided a review on the modeling of service life of massive concrete structures. They divided the models into two groups: deterministic models and the models considering the stochastic nature of cracking. However, their review was limited to finite element modeling. Meanwhile, Lacarrière et al. [83] reviewed the literature on the modeling of cement hydration induced heat development in massive concrete structures; they presented several approaches, such as affinity-based models, microstructural models, data mining, and inverse analysis.

The hydration process of concrete involves many disciplines, and therefore this paper has grouped the premature concrete cracking related models available in literature, according to the thermal, mechanical, chemical, and hygroscopic criteria (refer to Table 2). It was found that the mechanical criteria are involved in the most models, because stress and strain always play key roles in the development of cracking. Thermal stress and chemical reaction between cement and water are also associated with the cracking of concrete. Hydro-related criteria are involved too because of the moisture involvement and movement.

Table 2. Grouping of early-age cracking models for concrete structures.

\begin{tabular}{cccccc}
\hline No & Reference & Thermal & Mechanical & Chemical & Hygroscopic \\
\hline 1 & de Borst and Van den Boogaard [81] & $\mathrm{Y}$ & $\mathrm{Y}$ & - & - \\
2 & Emborg and Bernander [9] & $\mathrm{Y}$ & $\mathrm{Y}$ & - & - \\
3 & Ulm and Coussy [84] & $\mathrm{Y}$ & $\mathrm{Y}$ & $\mathrm{Y}$ & - \\
4 & Ulm and Coussy [85] & $\mathrm{Y}$ & - & $\mathrm{Y}$ & - \\
5 & Faria, Azenha, and Figueiras [86] & $\mathrm{Y}$ & $\mathrm{Y}$ & - & - \\
6 & Gawin, Pesavento, and Schrefler [87,88] & $\mathrm{Y}$ & $\mathrm{Y}$ & $\mathrm{Y}$ & $\mathrm{Y}$ \\
7 & De Schutter [89] & $\mathrm{Y}$ & $\mathrm{Y}$ & $\mathrm{Y}$ & - \\
8 & Azenha, Faria, and Ferreira [90] & $\mathrm{Y}$ & $\mathrm{Y}$ & - & - \\
9 & Li et al. [91] & $\mathrm{Y}$ & $\mathrm{Y}$ & - & - \\
10 & Liu et al. [42] & $\mathrm{Y}$ & $\mathrm{Y}$ & - & - \\
11 & Zhou et al. [92] & - & - & - & $\mathrm{Y}$ \\
12 & Briffaut et al. [71] & $\mathrm{Y}$ & $\mathrm{Y}$ & - & - \\
13 & Benboudjema and Torrenti [93] & $\mathrm{Y}$ & $\mathrm{Y}$ & $\mathrm{Y}$ & - \\
14 & Lawrence et al. [51] & $\mathrm{Y}$ & - & - & - \\
15 & Wu et al. [94] & $\mathrm{Y}$ & $\mathrm{Y}$ & $\mathrm{Y}$ & - \\
16 & Briffaut et al. [95] & $\mathrm{Y}$ & $\mathrm{Y}$ & - & - \\
17 & Kang et al. [96] & $\mathrm{Y}$ & - & $\mathrm{Y}$ \\
18 & Nehdi and Soliman [97] & - & $\mathrm{Y}$ & - & $\mathrm{Y}$ \\
19 & Klemczak and Knoppik-Wróbel [98] & $\mathrm{Y}$ & $\mathrm{Y}$ & - & $\mathrm{Y}$ \\
20 & Park [99] & $\mathrm{Y}$ & $\mathrm{Y}$ & $\mathrm{Y}$ & - \\
21 & Yuan and Wan [100] & - & $\mathrm{Y}$ & - \\
22 & De Schutter and Taerwe [38] & $\mathrm{Y}$ & - & - \\
\hline
\end{tabular}

Thermal stress is one of the main reasons of cracking in hardening concrete and therefore many researchers considered it in the modeling of early-age cracking. Bazant and L'Hermite [101] provided Double Power Law (DPL), which was used by de Borst and Van den Boogaard [81] to determine the stress evolution and crack propagation in concrete from finite element simulations. Emborg and Bernander [9] developed a theoretical model for thermal stress-induced cracking considering the influences of different measures against cracking as well as the influences of changes in temperature conditions, restraining, and mechanical behavior of concrete. They established a criterial stress level as the criterion of the risk of cracking by comparing the calculated tensile stress with the actual tensile strength of matured concrete. 
Faria et al. [86] presented a thermomechanical model to predict the hydration-induced volumetric changes in restrained concrete slab. The main parameters considered in the model were heat induced by cement hydration, the evolving properties of concrete during hydration, and early-age creep. De Schutter [89] also developed a simulation model on thermal cracking in massive hardening concrete elements based on the degree of hydration. Moreover, Wu et al. [94] developed a simulation model on the cracking risk of concrete due to thermal stress. The degree of hydration, thermal properties (such as specific heat and thermal diffusivity), thermal boundary conditions, and early-age mechanical properties (such as shrinkage and creep) were considered in this model.

A thermomechanical numerical model was also used by Azenha et al. [90] to identify the best strain gauges for monitoring concrete deformation during the early age. This model could be useful to predict the temperature and stresses in hardening concrete. This model could also predict the total strain developed in concrete during the early age.

Yuan and Wan [89] developed a micromechanical model and empirical formulas on the property development of young concrete to predict the potential early-age cracking after concrete placing. They observed the influences of environmental conditions and construction procedures, such as formwork removal, curing conditions, and variations in surrounding temperature and relative humidity on the early-age cracking behavior of concrete. Furthermore, Li et al. [91] used a concrete tensile creep law to predict the concrete temperature and stress evolution during the early age of a full scale diaphragm wall.

Ulm and Coussy $[84,85]$ worked on the thermo-chemo-mechanical modeling of concrete to predict the deformation and cracking at the macroscopic level. It is based on chemical hardening within the theory of elastoplasticity. After that, Gawin et al. [87] developed a hygro-thermo-chemo-mechanical model. This model involves the changes of the adsorption-desorption, evaporation-condensation, chemical reactions (hydration), different fluid flows, and the nonlinearities with regard to temperature and moisture content, as well as the progress of concrete maturity (hydration degree). A direct coupling between the shrinkage phenomenon and material creep has also been modeled through the modified microspore stress-solidification theory [88].

A nonlinear viscoelastic constitutive model for hardening concrete in an immersed tunnel was developed by Liu et al. [42], where casting temperature, formwork conductivity, formwork removal time, curing temperature, and ambient temperature are computed by a stochastic multiscale method to determine the uncertainty and identify the influencing factors. It was found out that the casting and curing temperatures are the most influencing factors in the model. Moreover, a new model on the internal relative humidity of concrete was developed by Zhou et al. [92] to determine the drying shrinkage stress and thermal dilation coefficient of concrete. The temperature, age, and internal relative humidity of concrete were considered in this model. It provides better results than the predrilled-hole method since the effect of environment was not taken into consideration.

Kang et al. [96] used an inverse numerical analysis to develop a model for the moisture diffusion coefficient by considering the relative humidity, temperature, and age of concrete. This model is able to describe the diffusion process occurring in early-age concrete. In the same year, Park [99] deduced three-dimensional finite element thermal analysis to predict the temperature and moisture distribution in hardening concrete. The fundamental parameter considered in his analysis was the degree of cement hydration. The effects of temperature, aging, and the variation of relative humidity due to moisture diffusion and self-desiccation were also considered in this model.

Many researchers have also developed models for massive concrete structures. Benboudjema and Torrenti [93] extended the basic creep model by including the effects of hydration to predict the behavior of a massive wall; they also used the concept of chemical affinity to predict the evolution of temperature and hydration. Besides, Briffaut et al. [95] developed a simulation model on the construction of a real massive structure to unveil the creep effect and creep-damage coupling. In this modeling exercise, the effects of environment, such as wind and ambient temperature, on the concrete properties were studied. In the simulation model on a massive wall [95], it was found that the ignorance 
in thermal properties and constant thermal capacity are the main reasons of error in the estimation of the stress that causes the early-age cracking in concrete.

Lawrence et al. [51] investigated the distribution of temperatures within a hardening massive concrete element using the finite element method. This model could quantify the maximum allowable temperature difference within the concrete core and surface to prevent cracking. The temperature distribution observed during the experiment was well quantified by the developed model. Moreover, Klemczak and Knoppik-Wróbel [98] developed a numerical model for analysis of the early-age thermal-shrinkage stresses in an externally restrained concrete wall and found that the restrain coefficient defines the inclination of the total stress curve in wall cross section. Temperature, moisture, and the chemical reactions of cement were mainly considered in this model. De Schutter and Taerwe [38] provided a better understanding of massive concrete by introducing the concept of equivalent thickness, which is defined for a separable heat flow area of concrete element, irrespective of the shape or size of concrete structure. The equivalent thickness concept could facilitate to provide a faster estimation of the early-age cracking tendency of massive concrete elements due to temperature rise. The cracking assessment was performed based on the conception of linear elastic stress without considering the shape of the concrete structure, that is, the estimation process is applicable to any shape of structure. It can be considered as an improvement in the modeling process, as the previous simulations of the early-age cracking in concrete were reliant on the shape of concrete structures.

Boshoff and Combrinck [102] proposed a simple model to predict the degree of plastic shrinkage cracking (PShC) in normal-strength concrete. The model is based on the amount of evaporated water from the freshly placed concrete before initial setting takes place, and can be expressed as follows.

$$
\text { PShC Severity }=E R \times t_{\text {set }}-W_{b l}
$$

where ER is the evaporation rate $\left(\mathrm{kg} / \mathrm{m}^{2} / \mathrm{h}\right), \mathrm{t}_{\text {set }}$ is the time between the concrete placement and the initial setting time $(\mathrm{h})$, and $\mathrm{W}_{\mathrm{bl}}$ is the total bleed water $\left(\mathrm{kg} / \mathrm{m}^{2}\right)$. Together with these parameters, drying time, air entry time, capillary water pressure, etc. are also carefully considered in the above model. The model demonstrates that the PShC will only occur once the bleed water is evaporated completely. The proposed PShC severity model efficiently correlated with the crack width induced by PShC in the case of a large number of concrete mixtures with or without reinforcing fibers. However, the authors did not consider the interaction between plastic settlement cracking (PSeC) and PShC. Due to this they observed some cracking in concrete even at a zero value of PShC severity.

Shrinkage induces cracks in concrete overlays depending on the shrinkage stress, thus an estimation of this parameter is very important in understanding the formation of such cracks. Many models have been proposed to determine the shrinkage stress; however, sometimes those models are very complicated for practical use. Kristiawan [103] proposed a simple model to predict the shrinkage stress in overlay concrete, which is as follows.

$$
\sigma=0.009 \varepsilon_{\text {sh }}
$$

where $\sigma$ is the shrinkage stress and $\varepsilon_{\mathrm{sh}}$ is the free shrinkage strain in overlay concrete. The model was proposed based on an important assumption that both the substrate and overlay concretes are free to shrink. As the model is very much simplified, it can be used only for the quantitative assessment of shrinkage cracking tendency in overlay concrete.

Most of the above-mentioned models were developed based on finite element and mathematical analyses, but some researchers have used Artificial Neural Network (ANN) to predict the early-age properties of hardening concrete. For example, Nehdi and Soliman [97] used ANN to predict the early-age autogenous shrinkage of concrete. Initially, the model was developed considering the concrete mixtures under different curing temperatures. Later, the developed model was tested considering the other criteria such as cement content, water-to-cement ratio, the type and percentage of supplementary cementitious material, total aggregate volume, and hydration age. The developed 
ANN model is able to predict the autogenous shrinkage behavior of traditional as well as high- or ultra-high-performance concrete mixture.

There are various models available to predict the early-age cracking in concrete structures; these models could help construction stakeholders understand the limitations of their design, especially at the early stage. These modeling approaches can be categorized into two groups: mechanism-based modeling and factor-based modeling. The examples of mechanism-based modeling are listed in Table 2, while one of the factor-based modeling examples is ANN [97]. However, it was observed from the review of literature that there were lacks of standardized modeling techniques for the early-age cracking in concrete. The input data and predicted outcome from each modeling exercise was different from researcher to researcher. Another problem is the different data required to model and simulate early-age cracking. This is also supported by Wyrzykowski et al. [104]. They examined seven models with experimental data to predict the heat of hydration, Young's modulus, and shear modulus of elasticity of the early-age cement paste and mortars, and found that only three models provided consistent findings with the experiments.

\section{Remedial Measures for Early-Age Cracking}

Early-age cracking always has some risks for concrete structures. However, these risks can be reduced through many remedial measures. The early-age cracking in concrete can be minimized by limiting temperature differences or using shrinkage reducing admixtures. Low-heat cement has been used to limit the temperature induced cracking in concrete. Also, shrinkage reducing admixtures have been used to decrease the stresses resulting from autogenous shrinkage [17].

Appropriate selection of the constituent materials for concrete, the correct mix design of concrete, the proper planning of concrete casting and construction sequence, the use of insulation for reducing thermal gradients, the installation of control joints, and the cooling of concrete before or after placing are some of the measures to minimize the risk of the early-age cracking in concrete structures [16].

Temperature or distribution reinforcement can be used to control cracks in hardening concrete structures. This type of reinforcement distributes early-age cracks and prevents the formation of through-cracks. Therefore, the strain capacity of reinforced concrete elements is significantly increased in the presence of distribution reinforcement. Also, the main reinforcement configuration is more important than the reinforcement ratio in controlling the cracking in reinforced concrete elements [17]. The probability of cracking is lower in heavily reinforced concrete (generally true for high-strength concrete) structures. Less cooling joints or fewer dilation joints are required to prevent the early-age through-cracking in reinforced concrete structures.

The depth of plastic shrinkage cracks can be determined by coring. The extent of random, longitudinal, and transverse cracking over time can be determined by drawing crack map. The depth of cracking and aggregate breakage in the cases of transverse, longitudinal, and corner cracks as well as the bonding of slab with sub-base in the case of random crack can be determined by coring. The bonding of slab with sub-base can be examined by conducting push-off test in the cases of random, transverse, and longitudinal cracks. The joint function can be examined via the pull-out test while investigating transverse and corner cracks. Employing a good quality curing compound in an adequate amount may reduce the extent of plastic shrinkage, random, longitudinal, transverse, and corner cracking [1]. Well-graded sand and combined aggregates are also conducive to decrease the degree of severity of plastic shrinkage and number of random, longitudinal, and transverse cracks.

From literature survey, the remedial measures can be classified into two groups: materials and design based remedial methods and construction based remedial methods (refer to Table 3). Constituent materials, concrete mix design, and structural design are classed as materials- and design-based remedial measures. In the case of construction based remedial measures, curing, placing sequence and environmental conditions, vibration, cooling method, and formwork are emphasized. 
Table 3. Classification of remedial measures to reduce early-age cracking in concrete.

\begin{tabular}{ccccccccccc}
\hline \multirow{2}{*}{ No } & \multirow{2}{*}{ Reference } & \multicolumn{3}{c}{ Designing } & \multicolumn{5}{c}{ Construction } \\
\cline { 3 - 9 } & & A & B & C & D & E & F & G & H \\
\hline 1 & Holt [24] & Y & Y & - & - & - & - & - & - \\
2 & Klemczak and Knoppik-Wróbel [10] & Y & Y & - & Y & Y & - & Y & - \\
3 & Krauss and Rogalla [28] & - & Y & - & Y & Y & - & - & - \\
4 & Emborg and Bernander [9] & - & Y & - & - & - & - & Y & - \\
5 & Shing and Abu-Hejleh [105] & Y & Y & - & Y & Y & - & - & - \\
6 & Babaei and Purvis [106] & Y & Y & - & - & Y & - & - & - \\
7 & French et al. [107] & Y & Y & Y & - & Y & - & - & - \\
8 & Dippenaar [53] & Y & - & Y & Y & - & Y & - & Y \\
9 & Combrinck and Boshoff [37] & - & Y & - & - & - & - & - & - \\
10 & Kwak and Ha [108] & - & - & - & - & Y & Y & - & - \\
11 & Ah-Sha, Sanders, and Saiidi [36] & - & - & - & - & Y & - & - & - \\
\hline
\end{tabular}

Legends: A: Concrete constituent materials, B: Concrete mix design, C: Structural design, D: Curing, E: Placing sequence and environment conditions, F: Vibration, G: Cooling method, and H: Formwork.

\subsection{Materials and Design Based Remedial Measures}

Cement is one of the important constituents of concrete. Selecting the appropriate cement is crucial to produce good concrete $[10,24,28,97]$. Holt [24] suggested the use of cement with low $\mathrm{C}_{3} \mathrm{~A}$ (tri-calcium aluminate) and high $\mathrm{C}_{2} \mathrm{~S}$ (di-calcium silicate) contents to reduce chemical shrinkage, but Shing and Abu-Hejleh [105], Babaei and Purvis [106], and French et al. [107] recommended the use of Type II cement because of its low heat of hydration. Shing and Abu-Hejleh [105] suggested the exclusive use of Type II cement with a maximum content of $279 \mathrm{~kg} / \mathrm{m}^{3}\left(470 \mathrm{lbs} / \mathrm{yd}^{3}\right)$, but French et al. [107] did not agree with this content and pointed out that a maximum cement content of $391 \mathrm{~kg} / \mathrm{m}^{3}\left(660 \mathrm{lbs} / \mathrm{yd}^{3}\right)$ could be used in all mix designs for concrete bridge decks.

The selection of aggregates should be carried out carefully. Babaei and Purvis [106] reported that sandstone with a low modulus of elasticity and high compressibility should be avoided because it is highly sensitive to shrinkage. They were also against the use of aggregates with relatively high water absorption. In addition, coarsely ground or slow reacting cement was recommended [10,24], but it was not recommended that superplasticizer be minimized or banned [24]. The use of silica fume was suggested with an amount of $\leq 6 \%$, and fly ash was recommended to be used with a content of $20 \%$, especially for hot-weather concreting $[9,105]$.

The use of concrete mix design with high water-to-cement ratio, adequate air content and limited or no silica fume was encouraged to reduce the cracking risk of concrete structures by producing a coarser pore structure [24]. Shing and Abu-Hejleh [105] recommended the use of water-to-cement ratio in the range of 0.38 to 0.47 and an air content at 7\%, but French et al. [107] suggested that a minimum air content of $6.0 \%$ and a maximum coarse aggregate content of $1098 \mathrm{~kg} / \mathrm{m}^{3}\left(1850 \mathrm{lbs} / \mathrm{yd}^{3}\right)$ should be used in concrete. It is also important to use the concrete mixtures with low settlement characteristic [37].

Combrinck and Boshoff [109] studied the effect of low volume microfibers (polyester and polypropylene fibers) on the plastic shrinkage cracking behavior of concrete. They observed that plastic shrinkage cracks rapidly grow after the initial setting time and stabilize before the final setting of concrete. The shear bond between fibers and fresh concrete paste plays a significant role in reducing plastic shrinkage cracks. The bond strength rapidly increases during the initial to final setting times. The utilization of microfibers reduces the extent of plastic shrinkage cracks by increasing the strain capacity of fresh concrete.

Afzal et al. [110] studied the effect of bentonite clay in reducing the early-age cracking due to autogenous shrinkage in high-performance concrete. Bentonite clay has the capability to absorb water and thus it is suitable for using as internal curing agent. It has been used as a 5-20\% replacement of cement by weight [110]. Research findings reveal that bentonite clay is able to reduce the autogenous shrinkage of concrete, and 10\% weight content shows the best performance. Afzal et al. [110] reported that the stability of bentonite clay to withstand high temperature gradients and its pozzolanic property 
are the two main reason of reducing the early-age autogenous shrinkage cracking susceptibility of concrete.

Fernandes et al. [111] studied the potential of using phase change materials (PCMs) to diminish the early-age thermal cracking in cement-based materials. PCMs are latent energy/heat storage media that absorb heat when temperature is high and release it when temperature is low. The utilization of PCMs in concrete helps keeping the heat of hydration within the acceptable limit and thus reduces the rate of deformation and stress development, decreasing the risk of early-age concrete cracking. PCMs were reported to be the governing factor in reducing thermal cracks in early-age concrete [111]. In addition, Šavija and Schlangen [112] and Šavija et al. [113] studied the application of PCMs in mitigating thermal cracking in early-age concrete. They also reported the potential of PCMs in reducing temperature and stresses during the hardening of concrete and cement paste.

Some design characteristics of concrete structures may also contribute to the early-age cracking in concrete. To minimize the cracking risk of concrete structures, the following directions are given by several researchers.

a. Increase the girder spacing to decrease girder restraint [107].

b. Avoid specifying the decks with a thickness of $165 \mathrm{~mm}\left(6 \frac{1}{2}\right.$ in.) and less [107].

c. Limit the transverse reinforcement steel size to No. 5 at $140 \mathrm{~mm}$ spacing ( $5 \frac{1}{2}$ in.) and/or No. 6 spaced at $178 \mathrm{~mm}$ (7 in.) [107].

d. Increase the ratio of concrete cover to reinforcement bar diameter [53].

\subsection{Construction Based Remedial Measures}

The selection of suitable formwork could reduce the risk of the early-age cracking in concrete [39]. Before starting the placing of concrete, it must be ensured that all formwork systems are installed accurately and securely to prevent any movement during casting. It is also recommended that the subgrade and formwork be wetted to reduce the amount of water absorbed and subsequently removed from the freshly cast concrete [53].

Concrete placing is one of the important procedures in the construction stage. However, the contractors should be aware of the factors that influence concrete placement. One of these factors is the volume of concrete to be placed [10]. Pouring the concrete in a huge amount will cause external loading on the existing concrete structure and lead to thermal dilation effects. Therefore, the concrete should be poured at the support sections after the mid-span section to minimize cracking in the negative moment zones [36]. In addition, the sequence of concrete placement should be planned properly to avoid cold joints [108]. In the construction of deep members, concrete should be cast into the deep section and allowed to settle before casting and compacting of the concrete in the top section.

The following procedures are suggested by several researchers to minimize the environmental effects on concrete pouring:

a. Deck pouring should only take place when the ambient temperature is above $7^{\circ} \mathrm{C}\left(40^{\circ} \mathrm{F}\right)$ and below $32^{\circ} \mathrm{C}\left(90^{\circ} \mathrm{F}\right)$, but it should be avoided when the maximum ambient temperature change is expected to be equal or greater than $10^{\circ} \mathrm{C}\left(50^{\circ} \mathrm{F}\right)$ [107].

b. Concrete pouring should be avoided in windy conditions [28].

c. Concrete casting should be restricted to an ambient temperature in the range of from $7^{\circ} \mathrm{C}\left(40^{\circ} \mathrm{F}\right)$ to $27^{\circ} \mathrm{C}\left(80^{\circ} \mathrm{F}\right)$, maintaining the concrete temperature at or above $10^{\circ} \mathrm{C}\left(50^{\circ} \mathrm{F}\right)$ for the first $72 \mathrm{~h}$, and limiting the fresh concrete temperature at placement to $27^{\circ} \mathrm{C}\left(80^{\circ} \mathrm{F}\right)$ [105].

External curing should be adopted to reduce water evaporation from the surface of concrete elements. Fourteen-day curing is strongly recommended, but 7-day curing is essential for concrete [28]. A suitable curing method includes curing with insulation, misting, wet blanket, and curing compound, which should be applied properly to fully cover the concrete surface $[10,28,105]$. The cooling methods using liquid nitrogen, cooling pipe, chilled water, and shaved or chipped ice are also suggested for use to control the heat in concrete elements $[9,10]$. 
The effect of vibrations on fresh concrete should not be ignored. Re-vibrating the concrete during its initial setting time can close the cracks in concrete elements [108]. For conventional concrete, the particle velocities in concrete up to one day old should not exceed $5 \mathrm{~mm} / \mathrm{s}$. Moreover, the vibrations of more than $50 \mathrm{~mm} / \mathrm{s}$ should not be applied to concrete that is one to seven days old [64]. This is because a vibration speed greater than $50 \mathrm{~mm} / \mathrm{s}$ would weaken the concrete elements by affecting the microstructure of concrete and thereby reducing its strength.

\section{Major Recommendations}

Based on the findings of the present study and the experience of the authors, the following key recommendations are made:

a. Determine whether the cracks are isolated or widespread and gather information relevant to the possible causes of cracking in concrete;

b. Apply an iteration process to identify one or more major causes and verify the major causes one by one with field observations;

c. Collect samples by coring and conducting laboratory testing when more rigorous data evaluation is required;

d. Employ one or more nondestructive on-site assessment such as ultrasonic testing and elastic modulus measurement through ambient response method to monitor and assess the early-age concrete properties that are intimately related with the early-age cracking in concrete elements;

e. Thoroughly review all materials and design features as well as check the major construction procedures if the cracks are widespread;

f. Develop a database to record, analyze, and examine the formation and causes of early-age cracks in concrete. The type, source, and location of cracks may vary. The database will allow for more accurate prediction and simulation of early-age cracks;

g. Improve workers' skills by providing necessary training prior to placement in concrete construction jobs;

h. Allow third-party examination for the analysis of crack-causing factors and the necessary remedial measures;

i. Smear dry cement powder on the concrete surface in the presence of bleed water to reduce the probability of the formation of early-age cracks in newly placed concrete elements;

j. Investigate how the structural capacity and function of concrete elements are affected due to early-age cracking;

k. Develop models that can account for the effect of reinforcement, particularly in the case of high-strength concrete.

\section{Concluding Remarks}

The early-age cracking problem is a commonly faced challenge in concrete construction. It should be noted that while the advancement of concrete engineering and technology has progressed remarkably in the last three decades, it did not provide any permanent solution to minimize the problem of early-age cracks in concrete. Although numerous research studies have been undertaken for many years to address the causes of the early-age cracking problem, there is still doubt whether this knowledge is actually reaching onsite practitioners. Indeed, a more realistic solution for the concrete cracking problem is not yet in sight. It cannot be denied that much of the solution to the early-age cracking problem relies on the construction practices on site. Improving the workers' skills by providing necessary training prior to placing them on concrete construction jobs may contribute to resolve this problem.

This paper attempts to provide the rationale of the early-age cracking in concrete by critically discussing the types of early-age crack, the causes or mechanisms of early-age cracking, the factors affecting the initiation and growth of early-age cracks, and the modeling of early-age cracking. 
In addition, the possible remedial measures to minimize the occurrence of early-age cracks in concrete have been thoroughly discussed.

Early-age cracks in concrete can occur in different forms. Different perspectives by researchers on classifying the types of early-age crack in concrete have been presented in this paper. Several researchers have classified cracks based on their causes, such as drying shrinkage and settlement cracks, while others have categorized them based on their characteristics, such as random, map, transverse, longitudinal, and corner cracks. The factors influencing the early-age cracking in concrete were categorized based on design process, materials and mix parameters, construction procedures, and environmental and external loading conditions.

The modeling tools available to simulate the early-age cracking in concrete have been grouped based on thermal, mechanical, chemical, and hygroscopic criteria, while the remedial measures to minimize the early-age cracking problem have been divided into two main categories, namely materials and design based remedial methods, and construction based remedial methods. The materials and design based remedial methods focus on constituent materials, concrete mix design and structural design, while the curing practice, placing sequence and environmental conditions, vibration, cooling method, and formwork are highlighted in construction based remedial measures. The last section of the paper has been dedicated to giving some recommendations for further investigation on various aspects of the early-age cracking in concrete, deriving from the critical review of the published research and the experience of the authors.

Author Contributions: M.S. conceptualized and designed the structure of the paper. All authors contributed more or less equally to the original draft preparation. M.S. and S.N.R. took the leading roles in reviewing and editing to improve the technical and writing quality of the paper.

Funding: This research received funding from Universiti Kebangsaan Malaysia and the Ministry of Education, Malaysia through the Dana Impak Perdana Grant (DIP-2017-002).

Acknowledgments: M.S. expresses sincere gratitude to Angelo Del Zotto School of Construction Management, George Brown College for supporting the study. A.B.M.A.K. is grateful to the Infrastructure University Kuala Lumpur for the support provided for this study. C.-O.W. and S.N.R. acknowledge the assistance provided by the Ministry of Education, Malaysia and Universiti Kebangsaan Malaysia for supporting this study.

Conflicts of Interest: The authors declare no conflicts of interest.

\section{References}

1. ACPA. Concrete Crack and Partial-Depth Spall Repair Manual for Airfields; American Concrete Pavement Association: Rosemont, IL, USA, 2003.

2. Bentz, D.P. A Review of Early-Age Properties of Cement-Based Materials. Cem. Concr. Res. 2008, 38, $196-204$. [CrossRef]

3. Stark, J. Recent Advances in the Field of Cement Hydration and Microstructure Analysis. Cem. Concr. Res. 2011, 41, 666-678. [CrossRef]

4. Kim, J.H.; Ferron, R.P.; Shah, S.P. Fresh Concrete and Its Significance for Sustainability. J. Sustain. Cem.-Based Mater. 2012, 1, 16-23. [CrossRef]

5. Kovler, K.; Roussel, N. Properties of Fresh and Hardened Concrete. Cem. Concr. Res. 2011, 41, 775-792. [CrossRef]

6. Nehdi, M.; Soliman, A. Early-age Properties of Concrete: Overview of Fundamental Concepts and State-of-the Art Research. Proc. Inst. Civ. Eng. Constr. Mater. 2011, 164, 57-77. [CrossRef]

7. Reinhardt, H.W. Characterization of Fresh and Early Age Concrete Using NDT. In Nondestructive Testing of Materials and Structures; Büyüköztürk, O., Taşdemir, M.A., Güneş, O., Akkaya, Y., Eds.; Springer Netherlands: Dordrecht, The Netherlands, 2013; pp. 407-421. ISBN 978-94-007-0723-8.

8. Mihashi, H.; Leite, J.P.D.B. State-of-the-Art Report on Control of Cracking in Early Age Concrete. J. Adv. Concr. Technol. 2004, 2, 141-154. [CrossRef]

9. Emborg, M.; Bernander, S. Assessment of Risk of Thermal Cracking in Hardening Concrete. J. Struct. Eng. 1994, 120, 2893-2912. [CrossRef] 
10. Klemczak, B.; Knoppik-Wróbel, A. Early Age Thermal and Shrinkage Cracks in Concrete Structures-Description of The Problem. Archit.-Civ. Eng.-Environ. 2011, 4, 35-48.

11. Holt, E.E. Early Age Autogenous Shrinkage of Concrete; Technical Research Centre of Finland: Espoo, Finland, 2001; Volume 446, ISBN 951-38-5870-7.

12. Holt, E.; Leivo, M. Cracking Risks Associated with Early Age Shrinkage. Cem. Conc. Compos. 2004, 26, 521-530. [CrossRef]

13. ACI Committee 224. Causes, Evaluation, and Repair of Cracks in Concrete Structures; American Concrete Institute: Farmington Hills, MI, USA, 2007; ISBN 9995899051.

14. Issa, M.A. Investigation of Cracking in Concrete Bridge Decks at Early Ages. J. Bridge Eng. 1999, 4, $116-124$. [CrossRef]

15. Hiller, J.E.; Roesler, J.R. Determination of Critical Concrete Pavement Fatigue Damage Locations Using Influence Lines. J. Transp. Eng. 2005, 131, 599-607. [CrossRef]

16. Bamforth, P.B. Early-Age Thermal Crack Control in Concrete; Construction Industry Research and Information Association: London, UK, 2007; p. 112. ISBN 978-0860176602.

17. Sule, M.; van Breugel, K. The Effect of Reinforcement on Early-Age Cracking due to Autogenous Shrinkage and Thermal Effects. Cem. Concr. Compos. 2004, 26, 581-587. [CrossRef]

18. Jensen, O.M.; Hansen, P.F. Influence of Temperature on Autogenous Deformation and Relative Humidity Change in Hardening Cement Paste. Cem. Concr. Res. 1999, 29, 567-575. [CrossRef]

19. Meagher, T.; Shanahan, N.; Buidens, D.; Riding, K.A.; Zayed, A. Effects of Chloride and Chloride-Free Accelerators Combined with Typical Admixtures on the Early-Age Cracking Risk of Concrete Repair Slabs. Constr. Build. Mater. 2015, 94, 270-279. [CrossRef]

20. Perumal, V. Early-Age Thermal Stress Analysis of Concrete. Master's Thesis, National University of Singapore, Singapore, 2009.

21. Harrison, T. Early-Age Thermal Crack Control in Concrete; CIRIA: London, UK, 1981; ISBN 0860171663.

22. Khan, A.A. Concrete Properties and Thermal Stress Analysis of Members at Early Ages. Ph.D. Thesis, McGill University Canada, Montreal, QC, Canada, 1995.

23. Branch, J.; Hannant, D.; Mulheron, M. Factors Affecting the Plastic Shrinkage Cracking of High-Strength Concrete. Mag. Concr. Res. 2002, 54, 347-354. [CrossRef]

24. Holt, E. Contribution of Mixture Design to Chemical and Autogenous Shrinkage of Concrete at Early Ages. Cem. Concr. Res. 2005, 35, 464-472. [CrossRef]

25. Mehta, P.K.; Monteiro, P.J. Concrete: Microstructure, Properties, and Materials; McGraw-Hill: New York, NY, USA, 2006; ISBN 978-0071797870.

26. Abel, J.; Hover, K. Effect of Water/Cement Ratio on the Early Age Tensile Strength of Concrete. J. Transp. Res. Board 1998, 1610, 33-38. [CrossRef]

27. Nguyen, D.; Dao, V. Tensile Properties of Early-Age Concrete. In Proceedings of the 27th Biennial National Conference of the Concrete Institute of Australia in conjunction with the 69th RILEM Week, Melbourne, Australia, 31 August-2 September 2015; pp. 1314-1324.

28. Krauss, P.D.; Rogalla, E.A. Transverse Cracking in Newly Constructed Bridge Decks; National Academy Press: Washington, DC, USA, 1996; ISBN 0309057167.

29. Bažant, Z.P.; Hauggaard, A.B.; Baweja, S.; Ulm, F.-J. Microprestress-Solidification Theory for Concrete Creep. I: Aging and Drying Effects. J. Eng. Mech. 1997, 123, 1188-1194. [CrossRef]

30. Bažant, Z.P.; Cusatis, G.; Cedolin, L. Temperature Effect on Concrete Creep Modeled by MicroprestressSolidification Theory. J. Eng. Mech. 2004, 130, 691-699. [CrossRef]

31. Pickett, G. The Effect of Change in Moisture-Content on the Creep of Concrete under a Sustained Load. J. Proc. 1942, 333-356. [CrossRef]

32. Bažant, Z.P.; Xi, Y. Drying Creep of Concrete: Constitutive Model and New Experiments Separating Its Mechanisms. Mater. Struct. 1994, 27, 3-14. [CrossRef]

33. De Schutter, G.; Taerwe, L. Specific Heat and Thermal Diffusivity of Hardening Concrete. Mag. Concr. Res. 1995, 47, 203-208. [CrossRef]

34. Wei, Y.; Hansen, W. Tensile Creep Behavior of Concrete Subject to Constant Restraint at Very Early Ages. J. Mater. Civ. Eng. 2012, 25, 1277-1284. [CrossRef]

35. Issa, M.A.; Yousif, A.A.; Issa, M.A. Effect of Construction Loads and Vibrations on New Concrete Bridge Decks. J. Bridge Eng. 2000, 5, 249-258. [CrossRef] 
36. Ah-Sha, H.H.; Sanders, D.H.; Saiidi, M.S. Early Age Shrinkage and Cracking of Nevada Concrete Bridge Decks; National Technical Information Service: Springfield, VA, USA, 2001.

37. Combrinck, R.; Boshoff, W. Influence of Restraint on the Early Age Cracking of Concrete with and without Fibres. In Proceedings of the 8th RILEM International Symposium on Fiber Reinforced Concrete: Challenges and Opportunities (BEFIB 2012), Guimarães, Portugal, 19-21 September 2012; Barros, J.A.O., Ed.; RILEM Publications SARL: Guimarães, Portugal, 2012; pp. 86-99.

38. De Schutter, G.; Taerwe, L. Estimation of Early-Age Thermal Cracking Tendency of Massive Concrete Elements by means of Equivalent Thickness. ACI Mater. J. 1996, 93, 403-408. [CrossRef]

39. Ulm, F.-J.; Coussy, O. What Is a "Massive" Concrete Structure at Early Ages? Some Dimensional Arguments. J. Eng. Mech. 2001, 127, 512-522. [CrossRef]

40. Dakhil, F.H.; Cady, P.D.; Carrier, R.E. Cracking of Fresh Concrete as Related to Reinforcement. ACI J. Proc. 1975, 72, 421-428. [CrossRef]

41. Harsh, S.; Darwin, D. Effects of Traffic Induced Vibrations on Bridge Deck Repairs; University of Kansas Center for Research, Inc.: Lawrence, KS, USA, 1984.

42. Liu, X.; Yuan, Y.; Su, Q. Sensitivity Analysis of the Early-Age Cracking Risk in an Immersed Tunnel. Struct. Concr. 2014, 15, 179-190. [CrossRef]

43. Massazza, F. Pozzolanic Cements. Cem Concr. Compos. 1993, 15, 185-214. [CrossRef]

44. Lura, P.; van Breugel, K.; Maruyama, I. Effect of Curing Temperature and Type of Cement on Early-Age Shrinkage of High-Performance Concrete. Cem. Conc. Res. 2001, 31, 1867-1872. [CrossRef]

45. Bentz, D.P.; Sant, G.; Weiss, J. Early-Age Properties of Cement-Based Materials. I: Influence of Cement Fineness. J. Mater. Civ. Eng. 2008, 20, 502-508. [CrossRef]

46. Ramézani, H.; Mounanga, P.; Jeong, J.; Bouasker, M. Role of Cement Paste Composition on the Self Induced Stress in Early-Age Mortars: Application of the Cosserat Size Number. Cem. Concr. Compos. 2013, 39, 43-59. [CrossRef]

47. Kockal, N.U.; Turker, F. Effect of Environmental Conditions on the Properties of Concretes with Different Cement Types. Constr. Build. Mater. 2007, 21, 634-645. [CrossRef]

48. Alsayed, S.; Amjad, M. Effect of Curing Conditions on Strength, Porosity, Absorptivity, and Shrinkage of Concrete in Hot and Dry Climate. Cem. Conc. Res. 1994, 24, 1390-1398. [CrossRef]

49. Bentz, D.P.; Peltz, M.A.; Winpigler, J. Early-age Properties of Cement-Based Materials. II: Influence of Water-to-Cement Ratio. J. Mater. Civil Eng. 2009, 21, 512-517. [CrossRef]

50. Powers, T.C.; Brownyard, T.L. Studies of the Physical Properties of Hardened Portland Cement Paste. ACI J. Proc. 1946, 101-132. [CrossRef]

51. Lawrence, A.M.; Tia, M.; Ferraro, C.C.; Bergin, M. Effect of Early Age Strength on Cracking in Mass Concrete Containing Different Supplementary Cementitious Materials: Experimental and Finite-Element Investigation. J. Mater. Civ. Eng. 2011, 24, 362-372. [CrossRef]

52. Shah, S.P.; Wang, K.; Weiss, W.J. Mixture Proportioning for Durable Concrete: Challenges and Changes. Concr. Int. 2000, 22, 73-78.

53. Dippenaar, J.D. The Tensile Properties of Early Age Concrete and The Experimental Apparatus Required for Its Determination. Master's Thesis, Stellenbosch University, Stellenbosch, South Africa, 2015.

54. Igarashi, S.; Bentur, A.; Kovler, K. Stresses and Creep Relaxation Induced in Restrained Autogenous Shrinkage of High-Strength Pastes and Concretes. Adv. Cem. Res. 1999, 11, 169-177. [CrossRef]

55. Sule, M.; van Breugel, K. Cracking Behaviour of Reinforced Concrete Subjected to Early-Age Shrinkage. Mater. Struct. 2001, 34, 284-292. [CrossRef]

56. Cortas, R.; Rozière, E.; Staquet, S.; Hamami, A.; Loukili, A.; Delplancke-Ogletree, M.-P. Effect of the Water Saturation of Aggregates on the Shrinkage Induced Cracking Risk of Concrete at Early Age. Cem. Concr. Compos. 2014, 50, 1-9. [CrossRef]

57. Dao, V.T.N.; Morris, P.H.; Dux, P.F. Crack Propagation in Concrete at Very Early Ages. Mag. Concr. Res. 2014, 66, 643-651. [CrossRef]

58. Hua, C.; Ehrlacher, A.; Acker, P. Analyses and Models of the Autogenous Shrinkage of Hardening Cement Paste: II. Modelling at Scale of Hydrating Grains. Cem. Concr. Res. 1997, 27, 245-258. [CrossRef]

59. Maclnnis, C.; Kosteniuk, P.W. Effectiveness of Revibration and High-Speed Slurry Mixing for Producing High-Strength Concrete. ACI J. Proc 1979, 76, 1255-1265. [CrossRef] 
60. Silfwerbrand, J. The Influence of Traffic-Induced Vibrations on the Bond between Old and New Concrete; Department of Structural Mechanics and Engineering, Royal Institute of Technology: Stockholm, Sweden, 1992.

61. Harsh, S.; Darwin, D. Traffic-Induced Vibrations and Bridge Deck Repairs. Concr. Int. 1986, 8, 36-42.

62. Ansell, A.; Silfwerbrand, J. The Vibration Resistance of Young and Early-Age Concrete. Struct. Concr. 2003, 4, 125-134. [CrossRef]

63. Akins, K.P.; Dixon, D.E. Concrete Structures and Construction Vibrations; American Concrete Institute: Farmington Hills, MI, USA, 1979; pp. 213-247.

64. Dowding, C.H.; Dowding, C. Construction Vibrations; Prentice Hall: Upper Saddle River, NJ, USA, 1996; Volume 610, ISBN 978-0132991087.

65. Shen, D.; Jiang, J.; Shen, J.; Yao, P.; Jiang, G. Influence of Curing Temperature on Autogenous Shrinkage and Cracking Resistance of High-Performance Concrete at an Early Age. Constr. Build. Mater. 2016, 103, 67-76. [CrossRef]

66. Shen, D.; Jiang, J.; Wang, W.; Shen, J.; Jiang, G. Tensile Creep and Cracking Resistance of Concrete with Different Water-To-Cement Ratios at Early Age. Constr. Build. Mater. 2017, 146, 410-418. [CrossRef]

67. Krell, W.C. The Effect of Coal Mill Vibration on Fresh Concrete. Concr. Int. 1979, 1, 31-34.

68. Hua, C.; Acker, P.; Ehrlacher, A. Analyses and Models of the Autogenous Shrinkage of Hardening Cement Paste: I. Modelling at Macroscopic Scale. Cem. Concr. Res. 1995, 25, 1457-1468. [CrossRef]

69. Charron, J.; Zuber, B.; Marchand, J.; Bissonnette, B.; Pigeon, M. Influence of Temperature on the Early-Age Behavior of Concrete. In Proceedings of the International RILEM Symposium on Concrete Science and Engineering: A Tribute to Arnon Bentur, Evanston, IL, USA, 22-24 March 2004; pp. 67-84.

70. Oh, B.H.; Choi, S.C.; Cha, S.W. Temperature and Relative Humidity Analysis in Early-Age Concrete Decks of Composite Bridges. In Measuring, Monitoring and Modeling Concrete Properties; Konsta-Gdoutos, M.S., Ed.; Springer Netherlands: Dordrecht, The Netherlands, 2006; pp. 305-316. ISBN 978-1-4020-5104-3.

71. Briffaut, M.; Benboudjema, F.; Torrenti, J.M.; Nahas, G. Numerical Analysis of the Thermal Active Restrained Shrinkage Ring Test to Study the Early Age Behavior of Massive Concrete Structures. Eng. Struct. 2011, 33, 1390-1401. [CrossRef]

72. Mustafa, M.; Yusof, K. Mechanical Properties of Hardened Concrete in Hot-Humid Climate. Cem. Concr. Res. 1991, 21, 601-613. [CrossRef]

73. Cusson, D.; Repette, W.L. Early-Age Cracking in Reconstructed Concrete Bridge Barrier Walls. ACI Mater. J. 2000, 97, 438-446. [CrossRef]

74. Furr, H.L.; Fouad, F.H. Bridge Slab Concrete Placed Adjacent to Moving Live Loads; Texas Transportation Institute: College Station, TX, USA, 1981.

75. Manning, D.G. Effects of Traffic-Induced Vibrations on Bridge-Deck Repairs. In NCHRP Synthesis of Highway Practice; Transportation Research Board: Washington, DC, USA, 1981.

76. Van Breugel, K. Self-Healing Material Concepts as Solution for Aging Infrastructure. In Proceedings of the 37th Conference on Our World in Concrete \& Structures, Singapore, 29-31 August 2012; pp. 1051-1057.

77. De Schutter, G. Durability of Marine Concrete Structures Damaged by Early Age Thermal Cracking. In Proceedings of the International RILEM Workshop on Life Prediction and Aging Management of Concrete Structures, Cannes, France, 16-17 October 2000; pp. 185-194.

78. Ba, H.; Su, A.; Gao, X.; Tao, Q. Cracking Tendency of Restrained Concrete at Early Ages. J. Wuhan Univ. Technol. Mater. Sci. Ed. 2008, 23, 263-267. [CrossRef]

79. Huang, H.; Ye, G.; Qian, C.; Schlangen, E. Self-healing in Cementitious Materials: Materials, Methods and Service Conditions. Mater. Des. 2016, 92, 499-511. [CrossRef]

80. Kumar, S.V.; GangaRao, H.V. Fatigue Response of Concrete Decks Reinforced with FRP Rebars. J. Struct. Eng. 1998, 124, 11-16. [CrossRef]

81. De Borst, R.; Van den Boogaard, A. Finite-Element Modeling of Deformation and Cracking in Early-Age Concrete. J. Eng. Mech. 1994, 120, 2519-2534. [CrossRef]

82. Francesco, P.; Agnieszka, K.; Vít;milauer; Matthieu, B.; Pierre, R. Numerical Modelling. In Thermal Cracking of Massive Concrete Structures; Fairbairn, E.M., Azenha, M., Eds.; Springer: Berlin, Germany, 2018; pp. 182-255. ISBN 3319766163.

83. Lacarrière, L.; Knoppik, A.; da Silva, W.R.L.; Honorio, T.; Šmilauer, V.; Asamoto, S.; Fairbairn, E.M.R. Hydration and Heat Development. In Thermal Cracking of Massive Concrete Structures; Fairbairn, E.M., Azenha, M., Eds.; Springer: Berlin, Germany, 2018; pp. 15-46. ISBN 3319766163. 
84. Ulm, F.-J.; Coussy, O. Modeling of Thermochemomechanical Couplings of Concrete at Early Ages. J. Eng. Mech. 1995, 121, 785-794. [CrossRef]

85. Ulm, F.-J.; Coussy, O. Strength Growth as Chemo-Plastic Hardening in Early Age Concrete. J. Eng. Mech 1996, 122, 1123-1132. [CrossRef]

86. Faria, R.; Azenha, M.; Figueiras, J.A. Modelling of Concrete at Early Ages: Application to an Externally Restrained Slab. Cem. Concr. Compos. 2006, 28, 572-585. [CrossRef]

87. Gawin, D.; Pesavento, F.; Schrefler, B.A. Hygro-Thermo-Chemo-Mechanical Modelling of Concrete at Early Ages and Beyond. Part I: Hydration and Hygro-Thermal Phenomena. Int. J. Numer. Methods Eng. 2006, 67, 299-331. [CrossRef]

88. Gawin, D.; Pesavento, F.; Schrefler, B.A. Hygro-Thermo-Chemo-Mechanical Modelling of Concrete at Early Ages and Beyond. Part II: Shrinkage and Creep of Concrete. Int. J. Numer. Methods Eng. 2006, 67, 332-363. [CrossRef]

89. De Schutter, G. Finite Element Simulation of Thermal Cracking in Massive Hardening Concrete Elements Using Degree of Hydration Based Material Laws. Comput. Struct. 2002, 80, 2035-2042. [CrossRef]

90. Azenha, M.; Faria, R.; Ferreira, D. Identification of Early-Age Concrete Temperatures and Strains: Monitoring and Numerical Simulation. Cem. Conc. Compos. 2009, 31, 369-378. [CrossRef]

91. Li, K.; Ju, Y.; Han, J.; Zhou, C. Early-Age Stress Analysis of a Concrete Diaphragm Wall through Tensile Creep Modeling. Mater. Struct. 2009, 42, 923-935. [CrossRef]

92. Zhou, J.; Chen, X.; Zhang, J.; Wang, Y. Internal Relative Humidity Distribution in Concrete Considering Self-Desiccation at Early Ages. Int. J. Phys. Sci. 2011, 6, 1604-1610. [CrossRef]

93. Benboudjema, F.; Torrenti, J.M. Early-Age Behaviour of Concrete Nuclear Containments. Nucl. Eng. Des. 2008, 238, 2495-2506. [CrossRef]

94. Wu, S.; Huang, D.; Lin, F.-B.; Zhao, H.; Wang, P. Estimation of Cracking Risk of Concrete at Early Age Based on Thermal Stress Analysis. J. Therm. Anal. Calorim. 2011, 105, 171-186. [CrossRef]

95. Briffaut, M.; Benboudjema, F.; Torrenti, J.-M.; Nahas, G. Effects of Early-Age Thermal Behaviour on Damage Risks in Massive Concrete Structures. Eur. J. Environ. Civ. Eng. 2012, 16, 589-605. [CrossRef]

96. Kang, S.-T.; Kim, J.-S.; Lee, Y.; Park, Y.-D.; Kim, J.-K. Moisture Diffusivity of Early Age Concrete Considering Temperature and Porosity. KSCE J. Civ. Eng. 2012, 16, 179-188. [CrossRef]

97. Boshoff, W.P.; Combrinck, R. Modelling the Severity of Plastic Shrinkage Cracking in Concrete. Cem. Concr. Res. 2013, 48, 34-39. [CrossRef]

98. Klemczak, B.; Knoppik-Wróbel, A. Comparative Study of Methods for Analysis of Early-Age Thermal-Shrinkage Stresses in Externally Restrained Concrete Structures. In Proceedings of the 10th International Conference on New Trends in Statics and Dynamics of Buildings, Faculty of Civil Engineering STU Bratislava, Bratislava, Slovakia, 3-5 October 2012; pp. 41-44.

99. Park, K.-B. Prediction of Temperature and Moisture Distributions in Hardening Concrete by Using a Hydration Model. Archit. Res. 2012, 14, 153-161. [CrossRef]

100. Yuan, Y.; Wan, Z. Prediction of Cracking within Early-Age Concrete Due to Thermal, Drying and Creep Behavior. Cem. Conc. Res. 2002, 32, 1053-1059. [CrossRef]

101. Bazant, Z.P.; L'Hermite, R. Mathematical Modeling of Creep and Shrinkage of Concrete; Wiley: New York, NY, USA, 1988; ISBN 0471920576.

102. Kristiawan, S.A. Performance Criteria to Assess Shrinkage Cracking Tendency in Concrete Overlay. Procedia. Eng. 2013, 54, 82-100. [CrossRef]

103. Nehdi, M.L.; Soliman, A.M. Artificial Intelligence Model for Early-Age Autogenous Shrinkage of Concrete. ACI Mater. J. 2012, 109, 353-362. [CrossRef]

104. Wyrzykowski, M.; Sanahuja, J.; Charpin, L.; Königsberger, M.; Hellmich, C.; Pichler, B.; Valentini, L.; Honório, T.; Smilauer, V.; Hajkova, K. Numerical Benchmark Campaign of COST Action TU1404-Microstructural Modelling. RILEM Tech. Lett. 2018, 2, 99-107. [CrossRef]

105. Shing, P.B.; Abu-Hejleh, N. Cracking in Bridge Decks: Causes and Mitigation; Colorado Department of Transportation: Denver, CO, USA, 1999.

106. Babaei, K.; Purvis, R.L. Prevention of Cracks in Concrete Bridge Decks; Pennsylvania Department of Transportation: Harrisburg, PA, USA, 1995.

107. French, C.E.; Eppers, L.; Le, Q.; Hajjar, J. Transverse Cracking in Bridge Decks: Field Study; Minnesota Department of Transportation: Saint Paul, MN, USA, 1999. 
108. Kwak, H.-G.; Ha, S.-J. Plastic Shrinkage Cracking in Concrete Slabs. Part II: Numerical Experiment and Prediction of Occurrence. Mag. Concr. Res. 2006, 58, 517-532. [CrossRef]

109. Combrinck, R.; Boshoff, W.P. Typical Plastic Shrinkage Cracking Behaviour of Concrete. Mag. Concr. Res. 2013, 65, 486-493. [CrossRef]

110. Afzal, S.; Shahzada, K.; Fahad, M.; Saeed, S.; Ashraf, M. Assessment of Early-Age Autogenous Shrinkage Strains in Concrete Using Bentonite Clay as Internal Curing Technique. Constr. Build. Mater. 2014, 66, 403-409. [CrossRef]

111. Fernandes, F.; Manari, S.; Aguayo, M.; Santos, K.; Oey, T.; Wei, Z.; Falzone, G.; Neithalath, N.; Sant, G. On the Feasibility of Using Phase Change Materials (PCMs) to Mitigate Thermal Cracking in Cementitious Materials. Cem. Concr. Compos. 2014, 51, 14-26. [CrossRef]

112. Šavija, B.; Schlangen, E. Use of Phase Change Materials (PCMs) to Mitigate Early Age Thermal Cracking in Concrete: Theoretical Considerations. Constr. Build. Mater. 2016, 126, 332-344. [CrossRef]

113. Šavija, B.; Zhang, H.; Schlangen, E. Influence of Microencapsulated Phase Change Material (PCM) Addition on (Micro) Mechanical Properties of Cement Paste. Materials 2017, 10, 863. [CrossRef] [PubMed]

(C) 2018 by the authors. Licensee MDPI, Basel, Switzerland. This article is an open access article distributed under the terms and conditions of the Creative Commons Attribution (CC BY) license (http://creativecommons.org/licenses/by/4.0/). 